\title{
Efficient $\alpha$-Mannosylation of Phenols: The Role of Carbamates as Scavengers for Activated Glycosyl Donors
}

\author{
Peter Schüler, Sebastian N. Fischer, Michael Marsch, Markus Oberthür* \\ Department of Chemistry, Philipps University Marburg, Hans-Meerwein-Straße, 35032 Marburg, Germany \\ Fax +49(6421)2822021; E-mail: oberthuer@chemie.uni-marburg.de \\ Received: 26.09.2012; Accepted after revision: 07.11.2012
}

\begin{abstract}
The boron trifluoride activation of trichloroacetimidate donors was found to be an efficient method for the $\alpha$-mannosylation of tyrosine-containing acceptors. Most notably, these conditions are compatible with the commonly used carbamate protecting groups, whereas trichloroacetimidate activation with trimethylsilyl triflate or the use of glycosyl sulfoxides led to diminished yields in the presence of carbamates. In these cases, the competing reaction of the activated donors with the carbamate group was identified as a problematic side reaction. Taking advantage of this reactivity, various glycosyl carbamates were generated for the first time under non-acidic glycosylation conditions by reaction of different Bocprotected amino acids and dipeptides with glycosyl sulfoxides under triflic anhydride activation.
\end{abstract}

Key words: glycosylation, natural products, phenols, sulfoxides, trichloroacetimidates

\section{Introduction}

The glycosylation of proteins and natural products is an efficient means for organisms to add an additional level of molecular complexity to the initial gene products. ${ }^{1}$ In the case of ribosomally encoded proteins, N-linked glycosylation of asparagine residues and $\mathrm{O}$-glycosylation of serine and threonine side chains are the most abundant structural motifs. Phenol glycosylation of tyrosine side chains, on the other hand, is far less common, and has mainly been identified in glycogenin, S-layer proteins, ${ }^{2}$ and most recently in amyloid precursor proteins and $\beta$-peptides connected to Alzheimer's disease. ${ }^{3}$

In contrast, microorganisms produce a number of secondary metabolites that carry a carbohydrate moiety on the phenolic hydroxy group of tyrosine or hydroxyphenylglycine derivatives, respectively. The glycosylation pattern of these metabolites is structurally more diverse than on the protein level and features mono-, di-, and oligosaccharides composed of a variety of $\alpha$ - or $\beta$-linked L- and D-sugars attached to the phenolic side chain. Prominent examples with interesting biological activity are different glycopeptide antibiotics, e.g. vancomycin, teicoplanin, ${ }^{4}$ and ramoplanin, ${ }^{5}$ and the recently discovered group of anti-HIV cyclopeptides, the mirabamides. ${ }^{6}$

Our group is specifically interested in the chemical synthesis of the mannopeptimycins, a group of glycopeptide

SYNTHESIS 2013, 45, 0027-0039

Advanced online publication: 07.12.2012

DOI: 10.1055/s-0032-1316820; Art ID: SS-2012-E0759-FA

(C) Georg Thieme Verlag Stuttgart · New York antibiotics with excellent activity against resistant bacterial strains (methicillin resistant Staphylococcus aureus, MRSA, and vancomycin resistant enterococci, VRE).

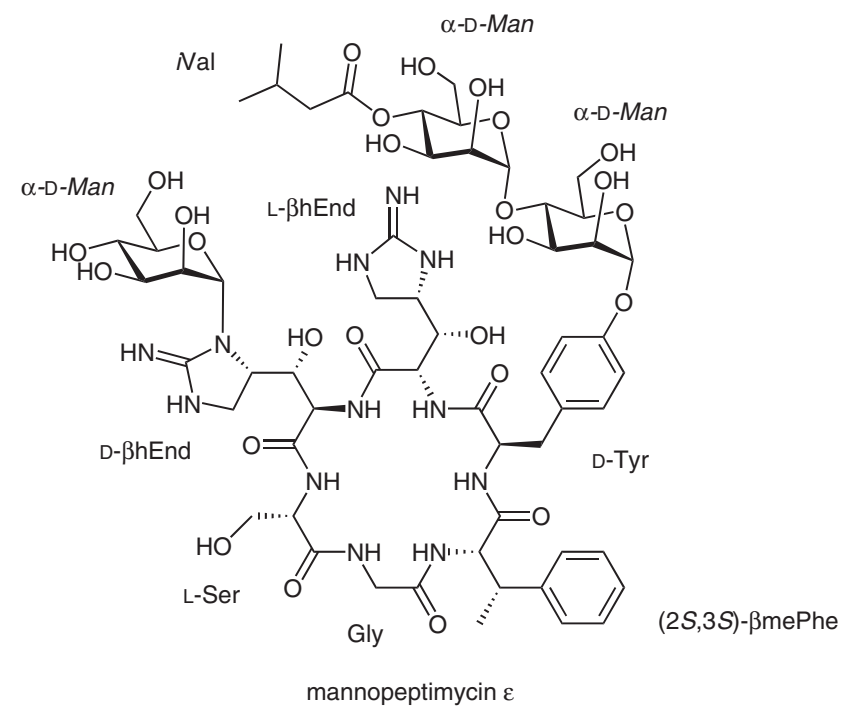

Figure 1 Structure of mannopeptimycin $\varepsilon$, the most active member of the naturally occurring mannopeptimycin antibiotics; $\beta \mathrm{hEnd}=\beta$ hydroxyenduracididine; $\beta$ mePhe $=\beta$-methylphenylalanine

The mannopeptimycins contain an $\alpha$-(1 $\rightarrow 4)$-linked dimannoside that is attached to a D-tyrosine side chain (Figure 1). ${ }^{7}$ Like the $4^{\prime}-O$-isovaleroyl derivative mannopeptimycin $\varepsilon$, the most active member of the group, all naturally occurring mannopeptimycins with antibiotic activity contain a dimannoside that carries the small hydrophobic isovaleroyl group at the terminal mannose unit, whereas the unusual N-linked D-mannose unit attached to the cyclic guanidine of D- $\beta$-hydroxyenduracididine (D$\beta \mathrm{hEnd}$ ) is not essential for activity. ${ }^{8}$

While no total synthesis of the mannopeptimycins has been accomplished so far, efforts towards glycosylated fragments and structural analogues have been reported. A group at Wyeth described the synthesis of a mannopeptimycin derivative that contains a structurally simplified cyclopeptide portion. ${ }^{9}$ Because an unmodified dimannoside was the initial synthetic target, acyl groups (Ac and $\mathrm{Bz}$ ) could be used as temporary protecting groups for the glycosyl donors that were required for the generation of an $\alpha$-(1 $\rightarrow 4)$-dimannosyl tyrosine building block. ${ }^{10}$ As a consequence, this synthetic design is not generally applicable for esterified derivatives like mannopeptimycin $\varepsilon$ 
because of difficulties associated with the selective removal of such acyl groups in the presence of other lipid esters. Following a completely different approach, the O'Doherty group has used $\alpha$-pyranone building blocks for the iterative construction of a mannopeptimycin $\varepsilon$ derived glycosylated D-tyrosine unit as well as a small set of structural analogues. ${ }^{11}$ Although efficient, this ingenious strategy will be limited in terms of introducing additional structural variations in the carbohydrate portion. Finally, the synthesis of a mannopeptimycin $\varepsilon$ derived dimannosyl $N$-phenyl trifluoroacetimidate has been reported, but this donor was so far only used for the glycosylation of the side chain of a $\beta$-lactam acceptor. ${ }^{12}$

Because of the limitations described above, we were looking for an efficient and flexible methodology to reliably attach different sugars to the tyrosine side chain via an $\alpha$ linkage. Published synthetic studies on phenol and tyrosine glycosylation, however, have so far mostly been directed at the synthesis of $\beta$-glycosides of carbohydrates with an equatorial 2-OH group, e.g. glucose and galactose. Accordingly, in these cases glycosyl donors with 2$O$-acyl groups were used, which ensured good $\beta$-selectivities by taking advantage of neighboring group participation. ${ }^{13-16}$ In principle, the same strategy can be used for the syntheses of $\alpha$-linked mannosides, because, in this case, neighboring group participation of the now axially oriented 2- $O$-acyl blocks the $\beta$-side. As described above, however, the use of 2-O-acylated donors is problematic for the synthesis of mannopeptimycin-type dimannosides with a $4^{\prime}-O$-acyl group.

\section{Biographical Sketches}

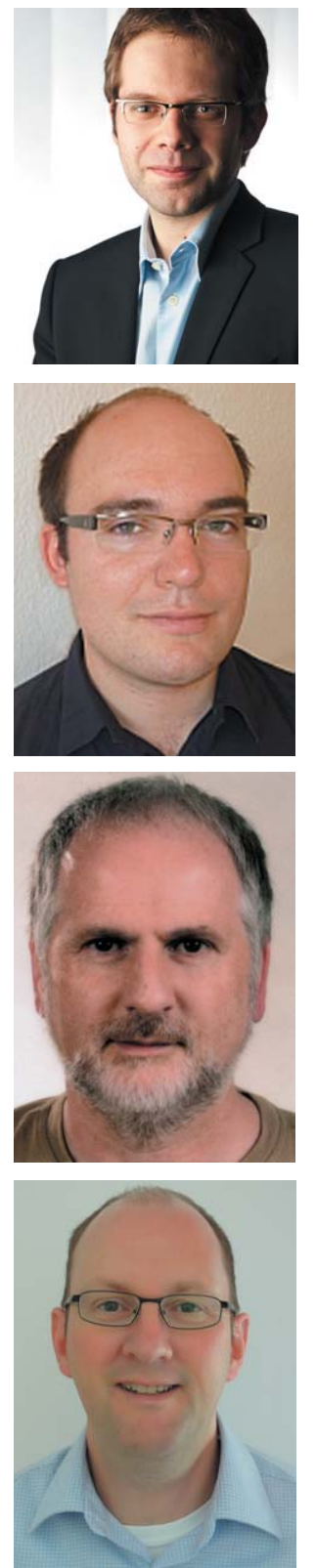

Peter Schüler studied chemistry at the Philipps University Marburg and the University of Cambridge, UK. He obtained his Ph.D. in 2012 for his work towards the total synthesis of

Sebastian Fischer studied chemistry at the Philipps University Marburg, where he received his Diploma in 2010 after completing a thesis on the synthesis of

Michael Marsch worked for 21 years in the group of Prof. Gernot Boche after finishing his training as a chemistry laboratory technician at the Philipps University Marburg in 1979.

Markus Oberthür obtained his Ph.D. in 1999 for work on the synthesis of galacto-oligosaccharides in the group of Prof. Frieder W. Lichtenthaler at the TU Darmstadt. After postdoctoral studies from 2000- the mannopeptimycins in the group of Dr. Markus Oberthür, where his main focus was the development of conditions for the efficient glycosylation of phenolic acceptors. Currently,

highly substituted $N$-hydroxyindoles. In April 2010, he started his $\mathrm{Ph}$.D. research under the guidance of Dr. Markus Oberthür and Prof. Armin Geyer. His current

During this time, his main focus was on the X-ray structure determination of oxenoid, nitrenoid, and carbenoid compounds. He is now a member of the Department of Crystallography he is a member of the Preclinical Target Development Group of Dr. Aubry K. Miller at the German Cancer Research Center, Heidelberg.

research is focused on the synthesis of nonproteinogenic amino acids and structurally complex peptides.

at Marburg, working on the field measurement and $\mathrm{X}$ ray crystal structure determination of small inorganic and organic molecules.

2005 with Prof. Daniel Kahne, first at Princeton University and then at Harvard University and Harvard Medical School, he moved to Marburg as a Junior Group Leader, where he completed his habilita- tion in 2012. His research interests include the chemistry and biology of cyclopeptides that act as antibiotics and antifungals as well as the bacterial iron transport mediated by siderophores. 
The formation of $\alpha$-glycosylated tyrosine derivatives by using donors that carry non-participating ether protecting groups at $\mathrm{O} 2$, on the other hand, has not been studied thoroughly, and only a few examples in which surprisingly low glycosylation yields were obtained, have been published. ${ }^{14 a, 17}$ Nevertheless, this second approach would not only avoid the tedious search for a compatible 2-O-acyl group but also simplify the synthesis of the required mannopeptimycin building blocks (vide infra). Accordingly, we surveyed a number of perbenzylated glycosyl donors regarding their performance in the $\alpha$-mannosylation of different tyrosine acceptors. Here, we present the results of these studies that concluded in the identification of reliable glycosylation conditions for structurally complex donors and acceptors.

\section{Results and Discussion}

Model glycosylations: In our efforts towards the efficient and reliable synthesis of $\alpha$-mannosylated tyrosine units, we evaluated various 'classical' mannosyl donors. These donors were uniformly protected with benzyl ethers, i.e. protecting groups that are orthogonal to the isovaleroyl ester present in the mannopeptimycin dimannosyl unit. Initially, the perbenzylated sulfoxide donor $\mathbf{1}$ was used, as glycosyl sulfoxides are known to be efficient donors for the glycosylation of phenols. ${ }^{18}$ Glycosylation of carbamate (Cbz) protected D-tyrosine methyl ester 3a with sulfoxide 1 under triflic anhydride activation led to the $\alpha$ mannosyl amino acid $\mathbf{4 a}$, albeit in only a moderate yield (45\% at best). The corresponding Alloc derivative gave similar results, whereas Boc- and Teoc-protected derivatives performed even worse (yields $<10 \%$ ). Interestingly, the use of acceptors $\mathbf{3 b}$ and $\mathbf{3} \mathbf{c}^{19}$ in which the amines are protected as amide groups (trifluoroacetyl) or masked as an azido group, led to much higher yields of the mannosylation products $4 \mathbf{b}$ and $\mathbf{4 c}(80 \%$ and $75 \%$, respectively).

The same dependence on the N-protecting group was observed when the corresponding trichloroacetimidate donor $\mathbf{2}$ was activated with trimethylsilyl triflate. Again, the carbamate-protected tyrosine $\mathbf{3 a}$ could be mannosylated in only $31 \%$ yield, whereas trifluoroacetamide derivate $\mathbf{3 b}$ led to mannoside $\mathbf{4 b}$ in $76 \%$ yield. Similar results were obtained with other glycosyl donors, e.g. the corresponding glucosyl and galactosyl derivatives. We were also able to show that the low yield for carbamate-containing acceptors was directly related to the phenolic glycosylation site and not to the instability of the carbamate group under the glycosylation conditions, because sulfoxide 1 could be used for the efficient glycosylation of the primary alcohol of Cbz-L-Ser-OMe.

The incompatibility of carbamate protecting groups with standard glycosyl donors for the generation of $\alpha$-glycosylated phenols would constitute a severe limitation for the synthesis of structurally complex carbohydrate-containing compounds because of the great utility of carbamates as $\mathrm{N}$-protecting group in general. ${ }^{20} \mathrm{~A}$ solution to this problem was ultimately found after screening additional activation conditions for trichloroacetimidate 2 . The best results were obtained when donor $\mathbf{2}$ was activated with boron trifluoride-diethyl ether complex instead of trimethylsilyl triflate, which led to vastly improved yields for carbamate-containing acceptors. As exemplified for Cbz-protected tyrosine 3a, the yield of mannoside 4a increased from $31 \%$ to $76 \%$ when mannosyl trichloroacetimidate 2 was activated with 0.6 equivalents of boron trifluoride-diethyl ether complex (Scheme 1) at $-30^{\circ} \mathrm{C}$. A similar increase was obtained for the mannosylation of the corresponding $N$-Alloc derivative. Not surprisingly, the activation method had no influence on the outcome of glycosylation reactions when acceptors without carbamate protecting groups were used, e.g. trifluoroacetamide $\mathbf{3 b}$ or azide $3 \mathbf{c}$. In conclusion, our experiments showed that the glycosylation of phenolic acceptors with highly reactive glycosyl donors like sulfoxide $\mathbf{1}$ (activated by $\mathrm{Tf}_{2} \mathrm{O}$ ) or trichloroacetimidate 2 (in combination with TMSOTf) was only successful if no carbamate protecting groups were present in the molecule. The activation of trichloroacetimidates with boron trifluoride, on the other hand, proved to be compatible with carbamates and afforded the glycosylated tyrosine derivatives in good yields.

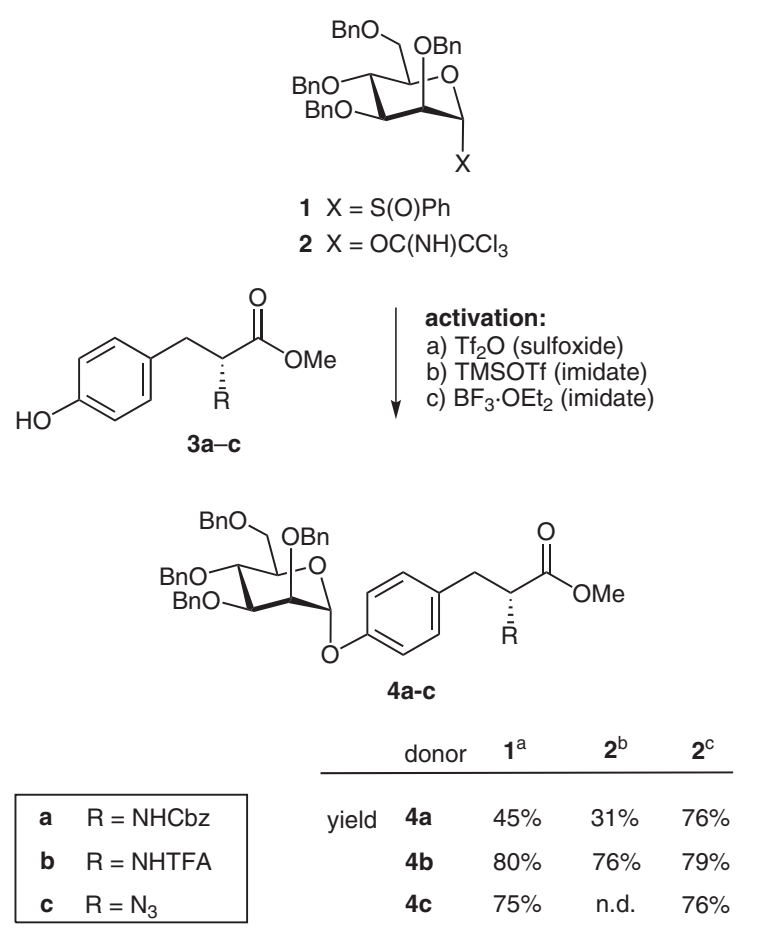

Scheme 1 Glycosylation of different D-tyrosine acceptors 3a-c with mannosyl sulfoxide $\mathbf{1}$ and trichloroacetimidate donor 2. Reagents and conditions: (a) $\mathrm{Tf}_{2} \mathrm{O}$ (1 equiv), DTBP, $\mathrm{CH}_{2} \mathrm{Cl}_{2},-60{ }^{\circ} \mathrm{C}$ to $-45^{\circ} \mathrm{C}$; (b) TMSOTf (0.8 equiv), $\mathrm{CH}_{2} \mathrm{Cl}_{2},-20{ }^{\circ} \mathrm{C}$ to $0{ }^{\circ} \mathrm{C}$; (c) $\mathrm{BF}_{3} \cdot \mathrm{OEt}_{2}(0.6$ equiv), $\mathrm{CH}_{2} \mathrm{Cl}_{2},-30{ }^{\circ} \mathrm{C}$ to $0{ }^{\circ} \mathrm{C}$. DTBP $=2,6$-di-tert-butylpyridine, $\mathrm{TFA}=$ trifluoroacetyl. 
Efficient glycosylation of mannopeptimycin precursor peptides: The results of our model studies were confirmed during the glycosylation of different mannopeptimycin precursor peptides. Towards this end, we synthesized the dimannosyl trichloroacetimidate donor $\mathbf{1 2}$ (Scheme 2) starting from the known mannoside $9 .{ }^{21}$ In addition to serving as the glycosyl acceptor, alcohol 9 can also be converted into an appropriate sulfoxide donor $\mathbf{1 0}$ by acylation $\left(i \mathrm{ValCl}, \mathrm{DMAP}, \mathrm{Et}_{3} \mathrm{~N}, \mathrm{CH}_{2} \mathrm{Cl}_{2}\right)$ to the $4-O-$ isovaleroyl derivative and subsequent oxidation with 3chloroperoxybenzoic acid (MCPBA; 76\% over 2 steps). Glycosylation of the thioglycoside acceptor 9 with sulfoxide 10 under triflic anhydride activation was rendered possible by the addition of 4-allyl-1,2-dimethoxybenzene to the reaction mixture, ${ }^{22}$ which afforded dimannoside $\mathbf{1 1}$ in acceptable yields. ${ }^{23}$

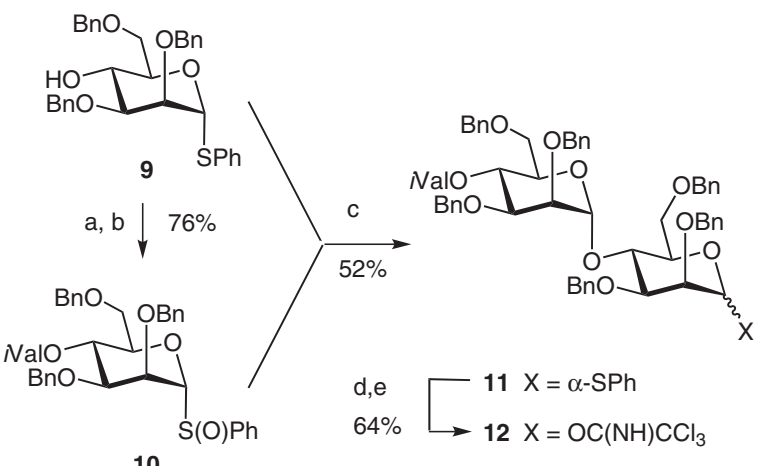

Scheme 2 Synthesis of dimannosyl building block 12. Reagents and conditions: (a) $i \mathrm{ValCl}$, DMAP, $\mathrm{Et}_{3} \mathrm{~N}, \mathrm{CH}_{2} \mathrm{Cl}_{2}, 0{ }^{\circ} \mathrm{C}$; (b) MCPBA, $\mathrm{CH}_{2} \mathrm{Cl}_{2},-70{ }^{\circ} \mathrm{C}$ to $-20{ }^{\circ} \mathrm{C}, 76 \%$ (2 steps); (c) $\mathrm{Tf}_{2} \mathrm{O}$, DTBP, 4-allyl1,2-dimethoxybenzene, $\mathrm{CH}_{2} \mathrm{Cl}_{2},-70{ }^{\circ} \mathrm{C}$ to $-25{ }^{\circ} \mathrm{C}, 52 \%$; (d) NBS, acetone $-\mathrm{H}_{2} \mathrm{O}, 0{ }^{\circ} \mathrm{C}, 81 \%$; (f) $\mathrm{Cl}_{3} \mathrm{CCN}, \mathrm{DBU}, \mathrm{CH}_{2} \mathrm{Cl}_{2}, 0{ }^{\circ} \mathrm{C}, 79 \%$.

Finally, thioglycoside $\mathbf{1 1}$ was transformed to the corresponding trichloroacetimidate donor $\mathbf{1 2}$ by hydrolysis of the thioglycoside (NBS, acetone $-\mathrm{H}_{2} \mathrm{O}$ ) and treatment of the resulting lactol with trichloroacetonitrile/DBU in good overall yield (66\%, 2 steps). Donor 12 was obtained as an anomeric mixture inseparable by flash chromatography and was used directly in the glycosylation reactions.

In parallel, we synthesized the Alloc-protected L- $\beta$ mePheD-Tyr dipeptide 13. The mannopeptimycin fragment $\mathbf{1 3}$ was assembled from a $(2 S, 3 S)-\beta$-methylphenylalanine derivative that was obtained conveniently through a newly developed route that features a diastereoselective Strecker reaction (see Supporting Information). Dipeptide 13 was efficiently glycosylated with trichloroacetimidate $\mathbf{1 2}$ to afford dimannosyl dipeptide $\mathbf{1 4}(60 \%)$ when the donor was activated with boron trifluoride ( 0.6 equiv; Scheme 3 ). It should be noted that glycosylation of the carbamate containing 13 with trichloroacetimidates under trimethylsilyl triflate activation or sulfoxides under triflic anhydride activation led to a significant decrease in the yields of the glycosylated dipeptide, similar to the results of our model studies.

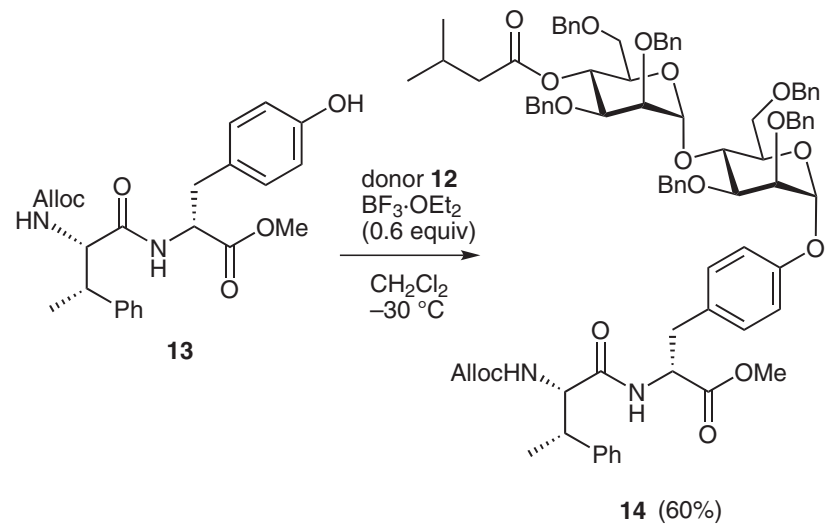

Scheme 3 Glycosylation of dipeptide $\mathbf{1 3}$ with dimannosyl donor $\mathbf{1 2}$

In addition to this dipeptide fragment, we also synthesized hexapeptide 15 (see Supporting Information), a linear hexapeptide precursor to the mannopeptimycins (Scheme 4). This acceptor contains two $\beta$-hydroxyenduracididine
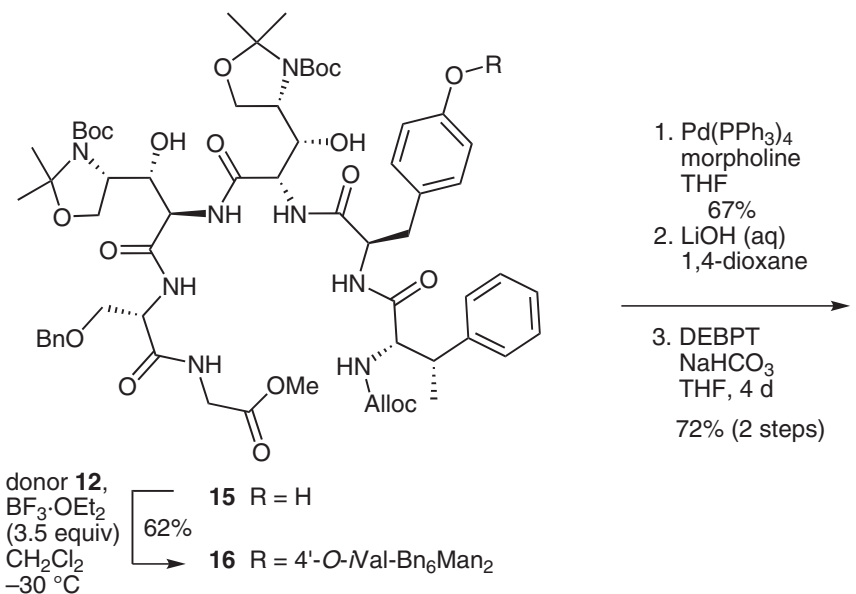

Scheme 4 Glycoslation of hexapeptide $\mathbf{1 5}$ and conversion into cyclopeptide 17

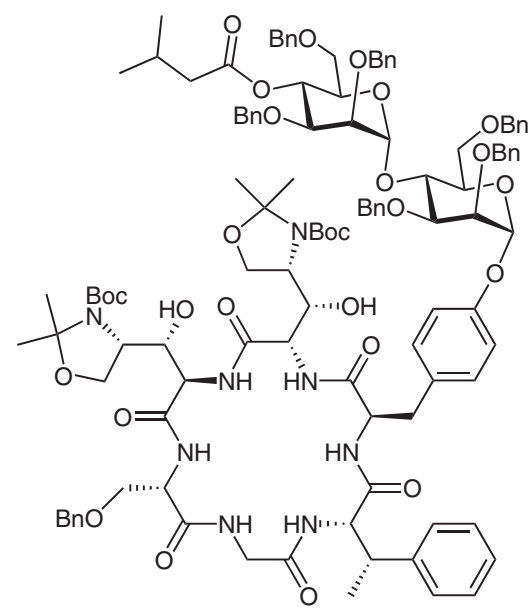

17 
analogues in which $N$-Boc-protected $N, O$-acetals serve as surrogates for the cyclic guanidine portion of these unusual amino acids. ${ }^{24}$ Gratifyingly, the structurally complex peptide $\mathbf{1 5}$ could also be efficiently glycosylated to afford 16 in $62 \%$ yield $(76 \%$ brsm) employing only a slight excess of trichloroacetimidate donor 12 (1.4 equiv). In comparison to previous reactions, it was imperative to raise the amount of boron trifluoride to 3.5 equivalents, presumably because of the larger number of carbonyl groups present in this acceptor, which might sequester some part of the Lewis acid through coordination. Following this successful glycosylation, the linear hexapeptide $\mathbf{1 6}$ could be deprotected at the $\mathrm{C}$-and $\mathrm{N}$-termini and cyclized to mannopeptimycin $\varepsilon$ precursor cyclopeptide 17 by using 3(diethoxyphosphoryloxy)-1,2,3-benzotriazin-4(3H)-one (DEPBT) for activation of the carboxylic acid.

Glycosyl carbamates: Even after the successful identification of generally applicable glycosylation conditions, the question remained why the trimethylsilyl triflate activation of trichloroacetimidates and sulfoxide activation with triflic anhydride, respectively, is incompatible with carbamate groups when very reactive perbenzylated donors are combined with less reactive phenolic acceptors. In our model studies, the glycosylation products of carbamate-protected acceptors were only isolated in yields below $50 \%$ for such combinations, and the only major additional reaction products following workup were the mannosyl lactol and the recovered acceptor. Other products of the glycosylation reaction remained elusive, e.g. $\beta$-anomers or C-glycosides ${ }^{25}$ as possible alternate glycosylation products, glycals resulting from elimination within the activated donor, ${ }^{26}$ or phenol triflates as a result of acceptor triflation. Therefore, the detection of an additional product that was formed in small amounts during the sulfoxide glycosylation of Boc- or Teoc-protected tyrosine methyl ester, the double glycosylation product $\mathbf{1 8}$ [Scheme 5 (A)], was extremely helpful for the interpretation of the observed reaction outcome. Obviously, in addition to the phenolic hydroxy group, the carbamate can also react with the activated glycosyl donor, which, after elimination of the tert-butyl or 2-(trimethylsilyl)ethyl group, respectively, led to the formation of a glycosyl carbamate.

To further investigate these findings, we submitted BocL-Phe-OMe to exactly the same glycosylation conditions [Scheme 5 (B)]. This carbamate-protected amino acid is missing a hydroxy group (alcohol or phenol) as a possible glycosylation site, and was converted in good yields into the carbamoyl-O-glycosylated product 19 [75\% after optimization of the reaction conditions: donor 1 (1.8 equiv), $-25^{\circ} \mathrm{C}, 18 \mathrm{~h}$ ]. The presence of a glycosyl carbamate in $\mathbf{1 9}$ was unambiguously proven by a crystal structure (Figure $2),{ }^{27}$ which also confirmed the $\alpha$-linkage of the mannose residue already assigned based on the ${ }^{3} J_{1,2}$ and ${ }^{1} J_{\mathrm{C}, \mathrm{H}}$ coupling constants ${ }^{28}(1.5 \mathrm{~Hz}$ and $177 \mathrm{~Hz}$, respectively) in the ${ }^{1} \mathrm{H}$ and HMBC spectra. Moreover, the fully protected 19 could be converted into the carboxylic acid $\mathbf{2 0}$ by treatment with aqueous lithium hydroxide solution in 1,4-di-

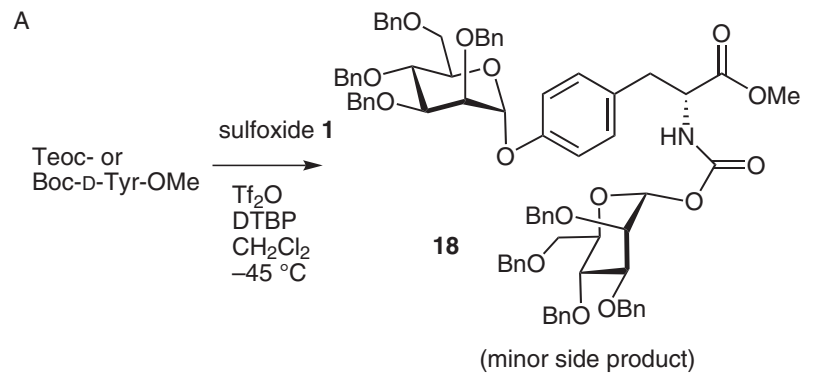

B
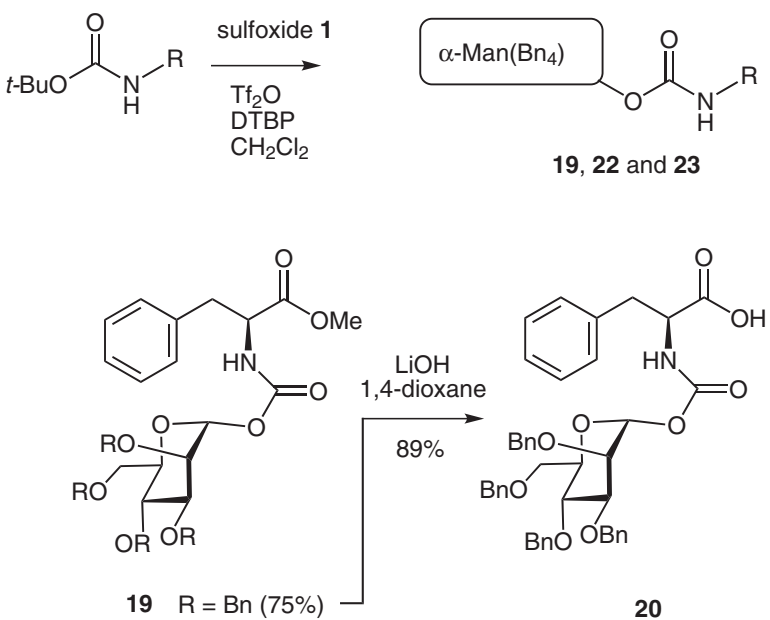

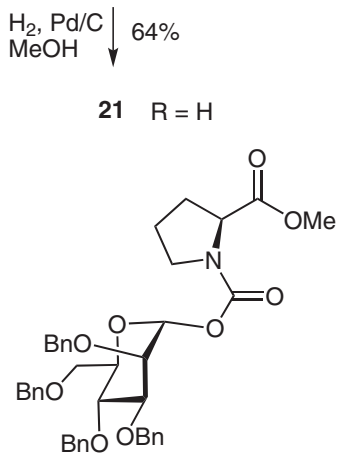

$22(79 \%)$

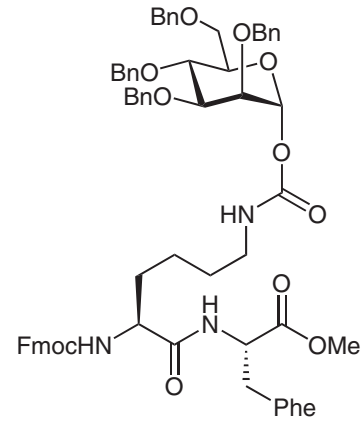

$23(44 \%)$
Scheme 5 Identification of glycosyl carbamates as reaction products. A: Side product 18 was identified by MS and ${ }^{1} \mathrm{H}$ NMR of crude product mixtures when Teoc-protected tyrosine acceptor was used and was isolated in $25 \%$ yield for the glycosylation of Boc-protected acceptor. B: Glycosyl carbamates 19, 22, and $\mathbf{2 3}$ were isolated as main products when Boc-containing compounds without any nucleophilic hydroxy groups were reacted with sulfoxide 1 under $\mathrm{Tf}_{2} \mathrm{O}$ activation.

oxane, thereby furnishing a potential coupling partner for ligation to an amino group. We were also able to remove the benzyl protecting groups of 19 by hydrogenation, which led to carbamate $\mathbf{2 1}$ with an unprotected mannose moiety.

To explore the scope of the reaction conditions, we tested additional amino acid substrates. First, we could show that carbamate-protected secondary amines are also glycosyl- 


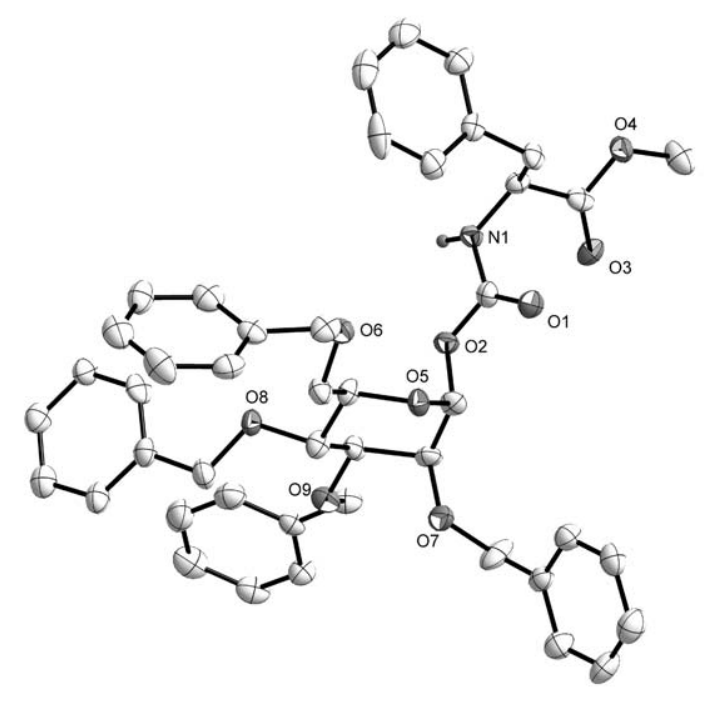

Figure 2 The single crystal X-ray structure of glycocarbamate $\mathbf{1 9}^{27}$ proves the $\alpha$-configuration $(\mathrm{O} 2)$ of the mannosyl carbamate. The thermal ellipsoids correspond to $50 \%$ probability.

ated. In the event, mannosylation of Boc-protected L-proline methyl ester with sulfoxide 1 led to glycosyl carbamate 22 with similar efficiency $(79 \%){ }^{29}$

Next, a chemoselective carbamate glycosylation was explored. In our model glycosylation reactions, glycosyl carbamates could only be detected when Boc and Teoc derivatives were used as acceptors. Because both groups contain reasonably good cationic leaving groups [the tertbutyl and 2-(trimethylsilyl)ethyl cation, respectively], we reasoned that other carbamates, e.g. Fmoc, that contain less-stabilized groups, could very well be tolerated. Indeed, we found that a Fmoc- and Boc-containing dipeptide [Fmoc-L-Lys(NHBoc)-L-Phe-OMe] could be converted into the monomannosyl carbamate $\mathbf{2 3}$, i.e. glycosylation was only observed in the lysine side chain, whereas the Fmoc group remained intact. ${ }^{30}$

Glycosyl carbamates have previously been prepared by different methods, most notably by the reaction of lactols with isocyanates, ${ }^{31}$ the reaction of amines with activated sugar carbamates ${ }^{32}$ or carbonates, ${ }^{33}$ and by the acid-catalyzed glycosylation of carbamate-protected amines with either glycosyl trichloroacetimidates ${ }^{34}$ or glycosyl or- thoesters. ${ }^{35}$ In the latter cases, the formation of glycosyl carbamates was also observed serendipitously as a byproduct of an attempted O-glycosylation of a Boc-protected amino acid acceptor. This outcome was proposed to evolve through the intermediacy of a carbamic acid generated via acid-catalyzed removal of the tert-butyl group, which subsequently serves as a glycosyl acceptor. ${ }^{35}$ Here, we observed this alternate reaction pathway for the first time under basic glycosylation conditions (sulfoxide activation with triflic anhydride in the presence of a pyridine base), which should exclude the formation of carbamic acids as reaction intermediates. Instead, the direct attack of the activated donor at the carbamate carbonyl group is most probably involved, which is then followed by elimination of the tert-butyl group. This reaction pathway is similar to the conversion of Boc-carbamates into trialkylsilyl carbamates when treated with trialkylsilyl triflates. ${ }^{36}$

Following this reasoning, such an attack of the activated glycosyl donor could also account for the three reaction outcomes that were observed when tyrosine acceptors are used. Firstly, in amide-protected derivatives, e.g. 3b, the carbonyl oxygen of the amide group is much less nucleophilic than the phenolic group, whereas in azide 3c, a possible second glycosylation site is missing completely. Accordingly, such acceptors are efficiently glycosylated at the phenolic hydroxy group with a variety of highly reactive glycosyl donors, e.g. 1 and $\mathbf{2}$, under different activation conditions. Secondly, in carbamate protected acceptors, e.g. 3a, the carbonyl oxygen of the carbamate group is only slightly less nucleophilic than the phenolic hydroxy group. As a result, a significant part of such acceptors is glycosylated at the carbamate group instead of the phenol when sulfoxide donors $\left(\mathrm{Tf}_{2} \mathrm{O}\right.$ activation) and trichloroacetimidate donors (TMSOTf activation) are used, i.e. under conditions that generate glycosyl triflates. In addition to the desired phenol glycoside $\mathbf{4 a}$, this would lead to intermediates of type $\mathbf{A}$ or their neutral elimination products B (Scheme 6). These intermediates, which effectively sequester the activated donor and prevent it from further glycosylating the phenolic group, are then hydrolyzed during the aqueous workup, either to the original carbamate $(\mathrm{R}=\mathrm{Cbz}$ or Alloc) or towards glycosyl carbamates $(\mathrm{R}=t$-Bu or Teoc $)$, i.e. depending on the stability of the cationic leaving groups liberated from the different carbamate groups. This interpretation would explain the

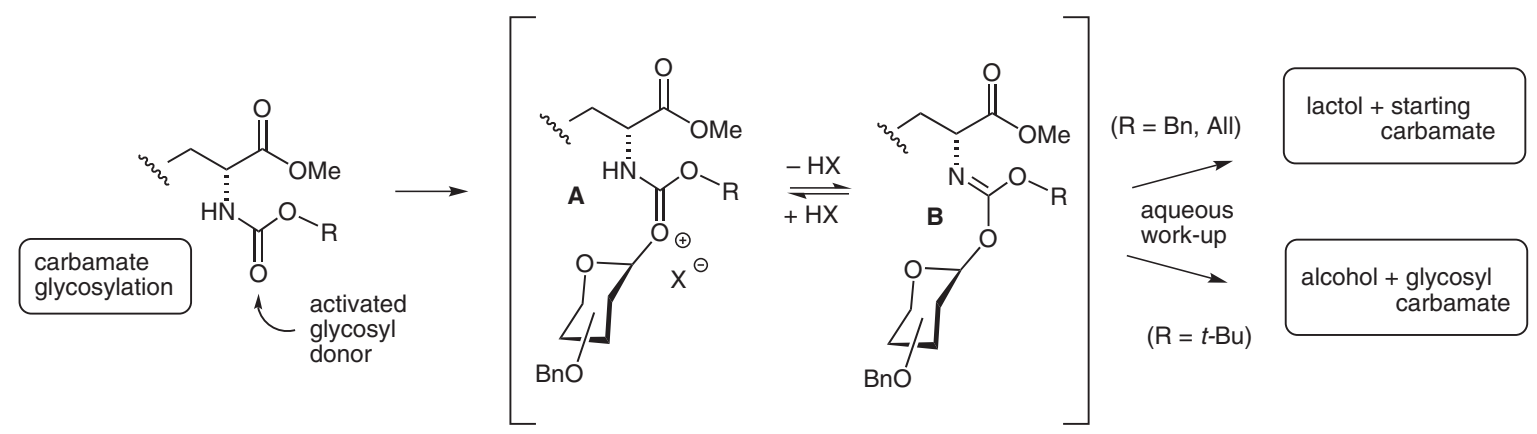

Scheme 6 Glycosylated carbamates of type A and their elimination products B could sequester the activated glycosyl donor. Upon hydrolysis, the observed reaction mixtures are formed depending on the relative stability of the two possible leaving groups (R vs. sugar). 
low yields for the tyrosine glycosylation irrespective of the type of carbamate group employed, as well as for formation of the minor side product $\mathbf{1 8}$ only in cases where reasonably good cationic leaving groups are present. So far, we have never observed glycosyl carbamates in the reaction mixture prior to aqueous workup, which also supports this view. Thirdly, and most importantly from a synthetic point of view, the activation of trichloroacetimidates with boron trifluoride is able to revert the reaction outcome towards predominant phenol glycosylation, irrespective of the N-protecting group. The activated donor that is formed in the presence of boron trifluoride preferentially reacts at the phenolic hydroxy group, possibly because this species is less reactive than the corresponding anomeric triflate generated by trimethylsilyl triflate activation. Further studies to provide additional experimental data concerning this mechanistic proposal are currently under way.

\section{Conclusion}

The glycosylation of phenolic hydroxy groups is widespread among natural products with interesting biological activity. The chemical glycosylation of such rather unreactive acceptors is still a challenge, because subtle changes of reaction conditions can have a profound impact on the efficiency of these transformations.

During our synthetic studies, we found that carbamate groups within the acceptor molecule have a negative impact on the glycosylation yield when two of the most common glycosyl donors are used, namely glycosyl trichloroacetimidates and sulfoxides. The diminished yields were traced back to a sequestration of the activated donor by the carbamate group, which in some cases led to glycosyl carbamates as side products. We were able to determine conditions that circumvent this problem, specifically the use of trichloroacetimidate donors that are activated by boron trifluoride. This methodology allows the efficient glycosylation of structurally complex peptides that contain multiple carbamate groups with monoand disaccharide donors, thus highlighting the reliability of the presented approach. ${ }^{37,38}$ These results are of importance for the glycosylation of phenolic acceptors in general and should be helpful for the proper choice of coupling partners and protecting group patterns used in future total synthesis efforts aimed at the generation of compounds containing glycosylated phenols.

In addition, the efficient and chemoselective generation of glycosyl carbamates under basic conditions using glycosyl sulfoxides and Boc-protected amino acids developed here nicely complements the known acid-mediated protocols for the formation of these glycoconjugates.

All reactions were carried out under an argon atmosphere. All chemicals were of reagent grade and were used as purchased. Solvents were dried according to established procedures. TLC was performed on silica gel $60 \mathrm{~F}_{254}$ plates (Merck KGaA). Detection was carried out by fluorescence quenching under UV light $(\lambda=254 \mathrm{~nm})$ or by staining with $20 \% \mathrm{H}_{2} \mathrm{SO}_{4}$ or ninhydrin soln followed by heating to ca. $300{ }^{\circ} \mathrm{C}$. Flash chromatography was performed on silica gel $60(0.040-0.063 \mathrm{~mm})$ from Merck KGaA. The petroleum ether (PE) used was of the fraction boiling in the $40-60{ }^{\circ} \mathrm{C}$ range. NMR spectra were recorded on Bruker AV 300, Bruker DRX 400, AV 500, DRX 500, and DRX 600 spectrometers at the NMR facilities, Philipps-Universität Marburg referenced to the solvent residual signal. All coupling constants are $J_{\mathrm{H}, \mathrm{H}}$ couplings unless indicated otherwise. All signals are described as they appear in the $1 \mathrm{D}^{1} \mathrm{H}$ NMR spectra, i.e. the actual multiplicitiy and not the expected one is given and the coupling constants of each signal are actual values for each signal and not averaged ones. Signals were assigned with the aid of COSY, HMBC and HMQC spectra. Diastereotopic protons are labeled according to their chemical shifts: $\delta_{\mathrm{a}}<\delta_{\mathrm{b}}$. In the NMR data listings, the $\beta$-hydroxyenduracididine precursor amino acids are abbreviated L- and D-Hep, respectively. HRMS (ESI) were acquired with a LTQ-FT mass spectrometer (Thermo Fischer Scientific); the resolution was set to 100.000 . The optical rotation was measured on a Perkin-Elmer 241 polarimeter.

Model glycosylations were performed according to General Procedure A or B. The acceptor phenols were prepared according to established procedures. For the synthesis of tyrosine derivatives 3a and $\mathbf{3 b}$, D-Tyr-OMe was acylated with benzyl chloroformate or trifluoroacetic anhydride, respectively. Azido-D-Tyr-OMe (3c) was prepared from D-Tyr-OMe using imidazole-1-sulfonyl azide. ${ }^{19}$ The perbenzylated sulfoxide 1 was prepared by MCPBA oxidation ${ }^{39}$ of the corresponding phenyl thioglycoside. ${ }^{40}$ The known trichloroacetimidate donor $\mathbf{2}$ was synthesized from the corresponding lactol (DBU, $\mathrm{Cl}_{3} \mathrm{CCN}$ ), which in turn was obtained from the phenyl thioglycoside by treatment with $\mathrm{NBS} / \mathrm{H}_{2} \mathrm{O} .{ }^{40}$ Mannoside 9 was prepared according to known procedures. ${ }^{21}$

Experimental details for the synthesis of $(2 S, 3 S)$ - $\beta$-methylphenylalanine, dipeptide 13, and hexapeptide 15 and copies of NMR spectra are given in the Supporting Information. Details of the synthesis of tetrapeptide S8 (see Supporting Information for the structure) will be described in a separate account.

\section{Mannosylation of Phenolic Acceptors with Sulfoxides; General Procedure A}

Sulfoxide $\mathbf{1}^{39,40}$ (1.5 equiv) and DTBP (3.0 equiv) were coevaporated with toluene $(2 \times)$ and dissolved in $\mathrm{CH}_{2} \mathrm{Cl}_{2}(5 \mathrm{~mL} / \mathrm{mmol}$ sulfoxide) under argon. After the addition of molecular sieves (4 $\AA$ ), the soln was stirred at r.t. (30 min). The soln was cooled to $-70{ }^{\circ} \mathrm{C}$ and $\mathrm{Tf}_{2} \mathrm{O}$ (1.5 equiv) was added. The mixture was stirred for $5 \mathrm{~min}$ at $-60{ }^{\circ} \mathrm{C}$, a soln of the acceptor 3 (1 equiv) [previously coevaporated with toluene $(2 \times)$ ] in $\mathrm{CH}_{2} \mathrm{Cl}_{2}(5 \mathrm{~mL} / \mathrm{mmol})$ was added, and the mixture was stirred at $-60{ }^{\circ} \mathrm{C}$ to $-45^{\circ} \mathrm{C}$ for $1 \mathrm{~h}$. The reaction was stopped by the addition of $\mathrm{MeOH}$, diluted with $\mathrm{CH}_{2} \mathrm{Cl}_{2}$, and poured into sat. aq $\mathrm{NaHCO}_{3}$-brine (1:1). The aqueous phase was extracted with $\mathrm{CH}_{2} \mathrm{Cl}_{2}(3 \times)$ and the combined organic phases were dried $\left(\mathrm{MgSO}_{4}\right)$, filtered, and evaporated. Purification of the residue by flash chromatography (PE-EtOAc, 2:1) gave the mannosylated phenol 4.

\section{Mannosylation of Phenolic Acceptors with Trichloroacetimi- dates; General Procedure B}

To a soln of 2,3,4,6-tetra- $O$-benzyl-mannose ${ }^{40}$ ( 1 equiv) and trichloroacetonitrile (4.5 equiv) in $\mathrm{CH}_{2} \mathrm{Cl}_{2}\left(20 \mathrm{~mL} / \mathrm{mmol}\right.$ lactol) at $0{ }^{\circ} \mathrm{C}$ was added DBU ( 0.3 equiv). After $30 \mathrm{~min}$ at this temperature, the mixture was evaporated and purified directly by flash chromatography (PE-EtOAc, 6:1 to 2:1), which gave trichloroacetimidate $\mathbf{2}$ as a colorless oil $(85-90 \%)$. To a soln of trichloroacetimidate 2 (1.5 equiv) and the acceptor 3 ( 1 equiv) in $\mathrm{CH}_{2} \mathrm{Cl}_{2}$ was added either TMSOTf ( 0.8 equiv based on donor 2$)$ at $-20{ }^{\circ} \mathrm{C}$ or $\mathrm{BF}_{3} \cdot \mathrm{OEt}_{2}(0.6$ equiv based on donor 2) at $-30^{\circ} \mathrm{C}$. The mixture was warmed to 0 ${ }^{\circ} \mathrm{C}$ over $1 \mathrm{~h}$ and the reaction was stopped by the addition of $\mathrm{Et}_{3} \mathrm{~N}$. Evaporation of the mixture and purification of the residue by flash chromatography (PE-EtOAc, 2:1) gave the mannosylated phenol 4. 


\section{Benzyloxycarbonyl-D-Tyr-O-(2,3,4,6-tetra- $O$-benzyl- $\alpha$-D-man- nopyranosyl)-OMe (4a)}

Mannoside 4a was prepared according to General Procedure A and $\mathrm{B}$ and was obtained as a colorless oil; yields: see Scheme 1; $R_{f}=$ 0.55 (PE-EtOAc, 2:1).

${ }^{1} \mathrm{H}$ NMR $\left(300 \mathrm{MHz}, \mathrm{DMSO}-d_{6}\right): \delta=2.80\left(\mathrm{dd},{ }^{2} J=13.6,{ }^{3} J_{\alpha, \beta \mathrm{a}}=\right.$ $\left.10.0 \mathrm{~Hz}, 1 \mathrm{H}, \beta-\mathrm{H}_{\mathrm{a}}^{\mathrm{Tyr}}\right), 2.97\left(\mathrm{dd},{ }^{2} J=13.6,{ }^{3} J_{\alpha, \beta \mathrm{b}}=5.0 \mathrm{~Hz}, 1 \mathrm{H}, \beta\right.$ $\left.\mathrm{H}_{\mathrm{b}}^{\text {Tyr }}\right), 3.52-3.75(\mathrm{~m}, 3 \mathrm{H}, \mathrm{H} 5,2 \mathrm{H} 6), 3.61\left(\mathrm{~s}, 3 \mathrm{H}, \mathrm{OCH}_{3}\right), 3.87(\mathrm{t}$ $\left.{ }^{3} J_{3,4}={ }^{3} J_{4,5}=9.2 \mathrm{~Hz}, 1 \mathrm{H}, \mathrm{H} 4\right), 3.98\left(\mathrm{dd},{ }^{3} J_{2,3}=2.9,{ }^{3} J_{3,4}=9.3 \mathrm{~Hz}, 1\right.$ $\mathrm{H}, \mathrm{H} 3), 4.09\left(\mathrm{dd},{ }^{3} J_{1,2}=2.1,{ }^{3} J_{2,3}=3.0 \mathrm{~Hz}, 1 \mathrm{H}, \mathrm{H} 2\right), 4.19(\mathrm{ddd}$ $\left.{ }^{3} J_{\alpha, \beta \mathrm{t}}=5.2,{ }^{3} J_{\alpha, \mathrm{NH}}=7.9,{ }^{3} J_{\alpha, \beta \mathrm{h}}=10.2 \mathrm{~Hz}, 1 \mathrm{H}, \alpha-\mathrm{H}^{\mathrm{Tyr}}\right), 4.35-4.81(\mathrm{~m}$, $\left.8 \mathrm{H}, 4 \mathrm{CH}_{2}^{\mathrm{Bn}}\right), 4.95$ and $5.00\left(2 \mathrm{~d},{ }^{2} J=12.6 \mathrm{~Hz}\right.$, each $\left.1 \mathrm{H}, \mathrm{CH}_{2}{ }^{\mathrm{Cbz}}\right)$, $5.69\left(\mathrm{~d},{ }^{3} J_{1,2}=1.9 \mathrm{~Hz}, 1 \mathrm{H}, \mathrm{H} 1\right), 6.93-7.04\left(\mathrm{~m}, 2 \mathrm{H}, o-\mathrm{H}_{\text {arom }}{ }^{\mathrm{Tyr}}\right)$, 7.11-7.47 (m, $\left.27 \mathrm{H}, \mathrm{H}_{\text {arom }}\right), 7.82\left(\mathrm{~d},{ }^{3} J_{\alpha, \mathrm{NH}}=8.2 \mathrm{~Hz}, 1 \mathrm{H}, \mathrm{NH}\right)$.

${ }^{13} \mathrm{C}$ NMR $\left(75 \mathrm{MHz}, \mathrm{CDCl}_{3}\right): \delta=37.4\left(\mathrm{C}-\beta^{\mathrm{Tyr}}\right), 52.3\left(\mathrm{OCH}_{3}\right), 55.6$ $\left(\mathrm{C}-\alpha^{\mathrm{Tyr}}\right), 65.4\left(\mathrm{CH}_{2}{ }^{\mathrm{Cbz}}\right), 68.8(\mathrm{C} 6), 70.8,71.9\left(\mathrm{CH}_{2}{ }^{\mathrm{Bn}}\right), 72.0(\mathrm{C} 5)$, 72.2, $74.1\left(3 \mathrm{CH}_{2}{ }^{\mathrm{Bn}}\right), 74.2(\mathrm{C} 2), 74.3(\mathrm{C} 4), 79.4(\mathrm{C} 3), 96.5(\mathrm{C} 1)$, 116.7, 121.1, 127.4, 127.6, 127.6, 127.7, 127.8, 127.9, 127.9, 128.1, $128.2,128.2,128.3,128.4,128.5,128.7,130.3\left(\mathrm{CH}_{\text {arom }}\right), 138.2$, $138.3,138.5,139.5\left(\mathrm{C}_{\text {arom }}\right), 150.4,155.0\left(\mathrm{C}_{\mathrm{arom}}{ }^{\mathrm{Tyr}}, \mathrm{C}=\mathrm{O}^{\mathrm{Cbz}}\right), 169.6$ (COOMe).

HRMS (ESI): $m / z[\mathrm{M}+\mathrm{Na}]^{+}$calcd for $\mathrm{C}_{52} \mathrm{H}_{53} \mathrm{NNaO}_{10}: 874.3567$; found: 874.3579 .

\section{Trifluoroacetyl-D-Tyr- $O$-(2,3,4,6-tetra- $O$-benzyl- $\alpha$-D-manno-} pyranosyl)-OMe (4b)

Mannoside 4b was prepared according to General Procedure A and $\mathrm{B}$ and was obtained as a colorless oil; yields: see Scheme $1 ; R_{\mathrm{f}}=$ 0.50 (PE-EtOAc, 2:1).

${ }^{1} \mathrm{H}$ NMR $\left(300 \mathrm{MHz}\right.$, DMSO- $\left.d_{6}\right): \delta=2.96\left(\mathrm{dd},{ }^{2} J=13.8,{ }^{3} J_{\alpha, \beta \mathrm{a}}=10.6\right.$ $\left.\mathrm{Hz}, 1 \mathrm{H}, \beta-\mathrm{H}_{\mathrm{a}}^{\mathrm{Tyr}}\right), 3.14\left(\mathrm{dd},{ }^{2} J=13.9,{ }^{3} J_{\alpha, \beta \mathrm{b}}=4.9 \mathrm{~Hz}, 1 \mathrm{H}, \beta-\mathrm{H}_{\mathrm{b}}{ }^{\mathrm{Tyr}}\right)$, 3.48-3.57 (m, $\left.1 \mathrm{H}, \mathrm{H6} 6_{\mathrm{a}}\right), 3.60-3.71\left(\mathrm{~m}, 5 \mathrm{H}, \mathrm{H} 5, \mathrm{H6}_{\mathrm{b}}, \mathrm{OCH}_{3}\right), 3.87$ $\left(\mathrm{t},{ }^{3} J_{3,4}={ }^{3} J_{4,5}=9.2 \mathrm{~Hz}, 1 \mathrm{H}, \mathrm{H} 4\right), 3.98\left(\mathrm{dd},{ }^{3} J_{2,3}=3.0,{ }^{3} J_{3,4}=9.2 \mathrm{~Hz}\right.$ $1 \mathrm{H}, \mathrm{H} 3), 4.08-4.13(\mathrm{~m}, 1 \mathrm{H}, \mathrm{H} 2), 4.31-4.84\left(\mathrm{~m}, 9 \mathrm{H}, 4 \mathrm{CH}_{2}{ }^{\mathrm{Bn}}, \alpha-\right.$ $\left.\mathrm{H}^{\mathrm{Tyr}}\right), 5.72\left(\mathrm{~d},{ }^{3} J_{1,2}=1.6 \mathrm{~Hz}, 1 \mathrm{H}, \mathrm{H1}\right), 7.01-7.44\left(\mathrm{~m}, 24 \mathrm{H}, \mathrm{H}_{\text {arom }}\right)$, $9.92\left(\mathrm{~d},{ }^{3} J_{\alpha, \mathrm{NH}}=8.0 \mathrm{~Hz}, 1 \mathrm{H}, \mathrm{NH}\right)$.

${ }^{13} \mathrm{C}$ NMR $\left(75 \mathrm{MHz}, \mathrm{DMSO}-d_{6}\right): \delta=34.8\left(\mathrm{C}-\beta^{\mathrm{Tyr}}\right), 52.4\left(\mathrm{OCH}_{3}\right), 54.1$ $\left(\mathrm{C}-\alpha^{\mathrm{Tyr}}\right), 68.7$ (C6), 70.8, $71.9\left(2 \mathrm{CH}_{2}{ }^{\mathrm{Bn}}\right), 72.0(\mathrm{C} 5), 72.2,74.1(2$ $\left.\mathrm{CH}_{2}{ }^{\mathrm{Bn}}\right), 74.1(\mathrm{C} 2), 74.2(\mathrm{C} 4), 78.9(\mathrm{C} 3), 95.6(\mathrm{C} 1), 116.7,127.3$, $127.4,127.5,127.5,127.6,127.7,127.7,128.1,128.2,128.2,130.1$ $\left(\mathrm{CH}_{\text {arom }}\right), 130.5,138.2,138.4,138.5\left(\mathrm{C}_{\text {arom }}\right), 154.5\left(\mathrm{OC}_{\text {arom }}\right), 156.3$ $\left(\mathrm{q},{ }^{3} J_{\mathrm{C}, \mathrm{F}}=36.8 \mathrm{~Hz}, \mathrm{C}=\mathrm{O}^{\mathrm{TFA}}\right), 170.4(\mathrm{COOMe})$.

HRMS (ESI): $m / z[\mathrm{M}+\mathrm{Na}]^{+}$calcd for $\mathrm{C}_{46} \mathrm{H}_{46} \mathrm{~F}_{3} \mathrm{NNaO}_{9}: 836.3022$; found: 836.3020 .

\section{Azido-D-Tyr-O-(2,3,4,6-tetra- $O$-benzyl- $\alpha$-D-mannopyranosyl)- \\ OMe (4c) \\ Mannoside 4c was prepared according to General Procedure A and $\mathrm{B}$ and was obtained as a colorless oil; yields: see Scheme $1 ; R_{f}=$ 0.45 (PE-EtOAc, 4:1). \\ ${ }^{1} \mathrm{H}$ NMR $\left(300 \mathrm{MHz}\right.$, acetone- $\left.d_{6}\right): \delta=2.96\left(\mathrm{dd},{ }^{2} J=14.1,{ }^{3} J_{\alpha, \beta a}=\right.$ $\left.8.5 \mathrm{~Hz}, 1 \mathrm{H}, \beta-\mathrm{H}_{\mathrm{a}}{ }^{\mathrm{Tyr}}\right), 3.12\left(\mathrm{dd},{ }^{2} J=14.1,{ }^{3} J_{\alpha, \beta \mathrm{b}}=5.4 \mathrm{~Hz}, 1 \mathrm{H}\right.$, $\left.\beta-\mathrm{H}_{\mathrm{b}}{ }^{\mathrm{Tyr}}\right), 3.62-3.88(\mathrm{~m}, 3 \mathrm{H}, \mathrm{H} 5,2 \mathrm{H} 6), 3.74\left(\mathrm{~s}, 3 \mathrm{H}, \mathrm{OCH}_{3}\right), 4.09(\mathrm{t}$, $\left.{ }^{3} J_{3,4}={ }^{3} J_{4,5}=9.2 \mathrm{~Hz}, 1 \mathrm{H}, \mathrm{H} 4\right), 4.09\left(\mathrm{dd},{ }^{3} J_{2,3}=2.9,{ }^{3} J_{3,4}=9.3 \mathrm{~Hz}, 1\right.$ $\mathrm{H}, \mathrm{H} 3), 4.17\left(\mathrm{dd},{ }^{3} J_{1,2}=2.1,{ }^{3} J_{2,3}=3.0 \mathrm{~Hz}, 1 \mathrm{H}, \mathrm{H} 2\right), 4.29(\mathrm{dd}$, $\left.{ }^{3} J_{\alpha, \beta \mathrm{b}}=5.4,{ }^{3} J_{\alpha, \beta \mathrm{a}}=8.5 \mathrm{~Hz}, 1 \mathrm{H}, \alpha-\mathrm{H}^{\mathrm{Tyr}}\right), 4.46-4.98(\mathrm{~m}, 8 \mathrm{H}, 4$ $\left.\mathrm{CH}_{2}{ }^{\mathrm{Bn}}\right), 5.69\left(\mathrm{~d},{ }^{3} J_{1,2}=1.9 \mathrm{~Hz}, 1 \mathrm{H}, \mathrm{H} 1\right), 7.04-7.11\left(\mathrm{~m}, 2 \mathrm{H}, \mathrm{CH}_{\text {arom }}\right)$, 7.16-7.39 (m, $\left.22 \mathrm{H}, \mathrm{CH}_{\text {arom }}\right)$. \\ ${ }^{13} \mathrm{C}$ NMR $\left(75 \mathrm{MHz}, \mathrm{CDCl}_{3}\right): \delta=37.2\left(\mathrm{C}-\beta^{\mathrm{Tyr}}\right), 52.8\left(\mathrm{OCH}_{3}\right), 63.8$ $\left(\mathrm{C}-\alpha^{\mathrm{Tyr}}\right), 70.3(\mathrm{C} 6), 72.5,73.5,73.7\left(3 \mathrm{CH}_{2}{ }^{\mathrm{Bn}}\right), 73.7(\mathrm{C} 5), 75.4$ $\left(\mathrm{CH}_{2}{ }^{\mathrm{Bn}}\right), 75.7(\mathrm{C} 4), 76.1(\mathrm{C} 2), 80.8$ (C3), 97.7 (C1), 116.7 (o- $\left.\mathrm{CH}_{\text {arom }}{ }^{\text {Tyr }}\right), 127.3,127.4,127.5,127.5,127.6,127.7,127.7,128.1$, $128.2,128.2,130.1\left(\mathrm{CH}_{\text {arom }}\right), 130.5,138.2,138.4,138.5\left(\mathrm{C}_{\text {arom }}\right)$, $154.5\left(\mathrm{OC}_{\text {arom }}\right), 170.4$ (COOMe). \\ HRMS (ESI): $m / z[\mathrm{M}+\mathrm{Na}]^{+}$calcd for $\mathrm{C}_{44} \mathrm{H}_{45} \mathrm{~N}_{3} \mathrm{NaO}_{8}: 766.3104$; found: 766.3115 .}

\section{Phenyl 2,3,6-Tri- $O$-benzyl-4- $O$-isovaleroyl-1-thio- $\alpha$-D-manno-} pyranoside $S$-Oxide (10)

Thioglycoside $\mathbf{9}^{21}(2.16 \mathrm{~g}, 3.98 \mathrm{mmol})$ and $\mathrm{Et}_{3} \mathrm{~N}(2.49 \mathrm{~mL}$, $17.8 \mathrm{mmol})$ were dissolved in $\mathrm{CH}_{2} \mathrm{Cl}_{2}(50 \mathrm{~mL})$. Isovaleroyl chloride $(1.41 \mathrm{~mL}, 11.9 \mathrm{mmol})$ and DMAP $\left(30 \mathrm{mg}\right.$, cat.) were added at $0{ }^{\circ} \mathrm{C}$ and the mixture was stirred for $6 \mathrm{~h}$ at $0{ }^{\circ} \mathrm{C}$. The reaction was quenched by the addition of $\mathrm{MeOH}(3 \mathrm{~mL})$ and diluted with $\mathrm{CH}_{2} \mathrm{Cl}_{2}$ $(100 \mathrm{~mL})$. The mixture was washed with $2 \mathrm{M} \mathrm{HCl}(50 \mathrm{~mL})$ and sat. aq $\mathrm{NaHCO}_{3}(50 \mathrm{~mL})$, and dried $\left(\mathrm{MgSO}_{4}\right)$; the solvent was evaporated to afford the crude 4- $O$-isovaleoryl derivative $(2.3 \mathrm{~g})$.

The crude 4-O-isovaleoryl derivative was dissolved in $\mathrm{CH}_{2} \mathrm{Cl}_{2}$ $(250 \mathrm{~mL})$ and was subsequently treated dropwise with a soln of MCPBA (70-75\%, $1.03 \mathrm{~g}, 4.2-4.5 \mathrm{mmol})$ in $\mathrm{CH}_{2} \mathrm{Cl}_{2}(100 \mathrm{~mL})$ at $-70{ }^{\circ} \mathrm{C}$. The mixture was slowly warmed to $-20^{\circ} \mathrm{C}$ over a period of $6 \mathrm{~h}$, and then sat. aq $\mathrm{NaHCO}_{3}(100 \mathrm{~mL})$ was added. After the addition of brine $(300 \mathrm{~mL})$, the phases were separated, the aqueous phase was extracted with $\mathrm{CH}_{2} \mathrm{Cl}_{2}(2 \times 200 \mathrm{~mL})$, and the combined organic phases were dried $\left(\mathrm{MgSO}_{4}\right)$ and evaporated. Purification of the residue by flash chromatography (PE-EtOAc, 4:1) afforded the sulfoxide 10 (3.08 g, 76\% over 2 steps) as a colorless amorphous powder; $R_{f}=0.35$ (PE-EtOAc, 4:1).

${ }^{1} \mathrm{H}$ NMR $\left(300 \mathrm{MHz}, \mathrm{CDCl}_{3}\right): \delta=0.89$ and $0.90\left(2 \mathrm{~d},{ }^{3} J=6.3 \mathrm{~Hz}\right.$, each $\left.3 \mathrm{H}, 2 \mathrm{CH}_{3}{ }^{i \mathrm{Val}}\right), 1.98-2.12\left(\mathrm{~m}, 3 \mathrm{H}, \mathrm{CH}_{2}{ }^{i \mathrm{Val}}, \mathrm{CH}^{i \mathrm{Val}}\right), 3.48-3.62$ $(\mathrm{m}, 2 \mathrm{H}, 2 \mathrm{H6}), 4.22\left(\mathrm{dd},{ }^{3} J_{2,3}=3.0,{ }^{3} J_{3,4}=9.5 \mathrm{~Hz}, 1 \mathrm{H}, \mathrm{H} 3\right), 4.23-$ 4.32 (m, $1 \mathrm{H}, \mathrm{H} 5), 4.33-4.36$ (m, $1 \mathrm{H}, \mathrm{H} 2), 4.42-4.56$ (m, $6 \mathrm{H}, 3$ $\left.\mathrm{CH}_{2}{ }^{\mathrm{Bn}}\right), 4.58\left(\mathrm{~d},{ }^{3} J_{1,2}=2.1 \mathrm{~Hz}, 1 \mathrm{H}, \mathrm{H1}\right), 5.39\left(\mathrm{t},{ }^{3} J_{3,4}={ }^{3} J_{4,5}=\right.$ $9.5 \mathrm{~Hz}, 1 \mathrm{H}, \mathrm{H} 4), 7.12-7.24\left(\mathrm{~m}, 5 \mathrm{H}, \mathrm{CH}_{\text {arom }}\right), 7.27-7.50(\mathrm{~m}, 13 \mathrm{H}$, $\left.\mathrm{CH}_{\text {arom }}\right), 7.54-7.59\left(\mathrm{~m}, 2 \mathrm{H}, \mathrm{CH}_{\text {arom }}\right)$.

${ }^{13} \mathrm{C} \mathrm{NMR}\left(75 \mathrm{MHz}, \mathrm{CDCl}_{3}\right): \delta=22.4\left(2 \mathrm{CH}_{3}{ }^{i \mathrm{Val}}\right), 25.5\left(\mathrm{CH}^{i \mathrm{Val}}\right), 43.3$ $\left(\mathrm{CH}_{2}{ }^{i \mathrm{Val}}\right), 67.6(\mathrm{C} 4), 70.0(\mathrm{C} 6), 71.0(\mathrm{C} 2), 72.6,72.6,73.5$ (3 $\left.\mathrm{CH}_{2}{ }^{\mathrm{Bn}}\right), 76.5$ (C5), 76.6 (C3), 95.8 (C1), 124.3, 127.7, 127.8, 128.0, $128.3,128.3,129.2,131.2\left(\mathrm{CH}_{\text {arom }}\right), 137.4,137.8,137.9,141.6$ $\left(\mathrm{C}_{\text {arom }}\right), 171.9(\mathrm{C}=\mathrm{O})$.

HRMS (ESI): $m / z[\mathrm{M}+\mathrm{Na}]^{+}$calcd for $\mathrm{C}_{38} \mathrm{H}_{42} \mathrm{NaO}_{7} \mathrm{~S}: 665.2543$; found: 665.2561 .

Phenyl 2,3,6-Tri-O-benzyl-4-O-(2',3',6'-tri-O-benzyl-4'-O-isovaleroyl-a-D-mannopyranosyl)-1-thio- $\alpha$-D-mannopyranoside (11)

Acceptor 9 (422 mg, $0.78 \mathrm{mmol}, 1.0$ equiv), DTBP $(0.52 \mathrm{~mL}$, $2.33 \mathrm{mmol}$, 3.0 equiv), and 4-allyl-1,2-dimethoxybenzene $(0.32 \mathrm{~mL}, 1.87 \mathrm{mmol}, 2.4$ equiv) were coevaporated with toluene ( 2 $\times 10 \mathrm{~mL})$. The residue was dissolved in $\mathrm{CH}_{2} \mathrm{Cl}_{2}(10 \mathrm{~mL})$, molecular sieves $(4 \AA)$ were added, and the resulting mixture was stirred at r.t. for 30 min under argon. The mixture was cooled to $-70{ }^{\circ} \mathrm{C}$ and then $\mathrm{Tf}_{2} \mathrm{O}(0.16 \mathrm{~mL}, 0.93 \mathrm{mmol}, 1.2$ equiv) was added dropwise, followed by a soln of sulfoxide 10 (600 $\mathrm{mg}, 0.93 \mathrm{mmol}, 1.2$ equiv) in $\mathrm{CH}_{2} \mathrm{Cl}_{2}(4 \mathrm{~mL})$. The mixture was slowly warmed to $-25^{\circ} \mathrm{C}$ over 1 h, quenched with $\mathrm{Et}_{2} \mathrm{NH}(0.4 \mathrm{~mL})$, diluted with $\mathrm{CH}_{2} \mathrm{Cl}_{2}(100 \mathrm{~mL})$, and poured into sat. aq $\mathrm{NaHCO}_{3}-$ brine $-\mathrm{H}_{2} \mathrm{O}(1: 1: 2,100 \mathrm{~mL})$. The aqueous phase was extracted with $\mathrm{CH}_{2} \mathrm{Cl}_{2}(2 \times 50 \mathrm{~mL})$ and the combined organic phases were dried $\left(\mathrm{MgSO}_{4}\right)$ and evaporated. Purification of the residue by flash chromatography (PE-EtOAc, 10:1, 8:1, $6: 1)$ afforded disaccharide $11(427 \mathrm{mg}, 52 \%)$ as a colorless syrup; $R_{f}=0.45$ (PE-EtOAc, 4:1).

${ }^{1} \mathrm{H}$ NMR $\left(500 \mathrm{MHz}, \mathrm{CDCl}_{3}\right): \delta=0.87$ and $0.88\left(2 \mathrm{~d},{ }^{3} J=6.6 \mathrm{~Hz}\right.$, each $\left.3 \mathrm{H}, 2 \mathrm{CH}_{3}{ }^{i \mathrm{Val}}\right), 1.97-2.10\left(\mathrm{~m}, 3 \mathrm{H}, \mathrm{CH}^{i \mathrm{Val}}, \mathrm{CH}_{2}{ }^{i \mathrm{Val}}\right), 3.47(\mathrm{dd}$, $\left.{ }^{2} J=10.6,{ }^{3} J_{5^{\prime}, 6 \mathrm{a}^{\prime}}=2.8 \mathrm{~Hz}, 1 \mathrm{H}, \mathrm{H}^{\prime}{ }_{\mathrm{a}}\right), 3.53\left(\mathrm{dd},{ }^{2} J=10.6\right.$, $\left.{ }^{3} J_{5^{\prime}, 6 \mathrm{~b}^{\prime}}=6.2 \mathrm{~Hz}, 1 \mathrm{H}, \mathrm{H6}^{\prime} \mathrm{b}\right), 3.72\left(\mathrm{dd},{ }^{3} J_{1^{\prime}, 2^{\prime}}=2.5,{ }^{3} J_{2^{\prime}, 3^{\prime}}=2.8 \mathrm{~Hz}, 1 \mathrm{H}\right.$, $\left.\mathrm{H} 2^{\prime}\right), 3.73\left(\mathrm{dd},{ }^{3} J_{2,3}=2.9,{ }^{3} J_{3,4}=9.2 \mathrm{~Hz}, 1 \mathrm{H}, \mathrm{H} 3\right), 3.83(\mathrm{dd}$, $\left.{ }^{3} J_{2^{\prime}, 3}=2.9, \quad{ }^{3} J_{3^{\prime}, 4^{\prime}}=9.6 \mathrm{~Hz}, 1 \mathrm{H}, \mathrm{H} 3^{\prime}\right), 3.83\left(\mathrm{dd},{ }^{2} J=10.8\right.$, $\left.{ }^{3} J_{5,6 \mathrm{a}}=6.9 \mathrm{~Hz}, 1 \mathrm{H}, \mathrm{H6} 6_{\mathrm{a}}\right), 3.93\left(\mathrm{ddd},{ }^{3} J_{5^{\prime}, 6^{\prime} \mathrm{a}}=2.7,{ }^{3} J_{5^{\prime}, 6^{\prime} \mathrm{b}}=6.2\right.$, $\left.{ }^{3} J_{4^{\prime}, 5^{\prime}}=9.7 \mathrm{~Hz}, 1 \mathrm{H}, \mathrm{H} 5^{\prime}\right), 3.96\left(\mathrm{dd},{ }^{2} J=11.1,{ }^{3} J_{5,6 \mathrm{~b}}=1.9 \mathrm{~Hz}, 1 \mathrm{H}\right.$, $\left.\mathrm{H}_{\mathrm{b}}\right), 4.00\left(\mathrm{dd},{ }^{3} J_{1,2}=2.0,{ }^{3} J_{2,3}=3.1 \mathrm{~Hz}, 1 \mathrm{H}, \mathrm{H} 2\right), 4.12\left(\mathrm{t},{ }^{3} J_{3,4}=\right.$ $\left.{ }^{3} J_{4,5}=9.3 \mathrm{~Hz}, 1 \mathrm{H}, \mathrm{H} 4\right), 4.28-4.36\left(\mathrm{~m}, 5 \mathrm{H}, \mathrm{H} 5,2 \mathrm{CH}_{2}{ }^{\mathrm{Bn}}\right), 4.45-4.70$ $\left(\mathrm{m}, 8 \mathrm{H}, 4 \mathrm{CH}_{2}^{\mathrm{Bn}}\right), 5.31\left(\mathrm{~d},{ }^{3} J_{1^{\prime}, 2^{\prime}}=2.2 \mathrm{~Hz}, 1 \mathrm{H}, \mathrm{H} 1^{\prime}\right), 5.37(\mathrm{dd}$, $\left.{ }^{3} J_{3^{\prime}, 4^{\prime}}=9.7,{ }^{3} J_{4^{\prime}, 5^{\prime}}=9.8 \mathrm{~Hz}, 1 \mathrm{H}, \mathrm{H} 4^{\prime}\right), 5.61\left(\mathrm{~d},{ }^{3} J_{1,2}=1.9 \mathrm{~Hz}, 1 \mathrm{H}\right.$, $\mathrm{H1}), 7.15-7.56\left(\mathrm{~m}, 35 \mathrm{H}, \mathrm{CH}_{\text {arom }}\right)$. 
${ }^{13} \mathrm{C} \mathrm{NMR}\left(126 \mathrm{MHz}, \mathrm{CDCl}_{3}\right): \delta=22.6\left(2 \mathrm{CH}_{3}{ }^{i \mathrm{Val}}\right), 25.6\left(\mathrm{CH}^{i \mathrm{Val}}\right)$, $43.6\left(\mathrm{CH}_{2}{ }^{i \mathrm{Val}}\right), 68.7\left(\mathrm{C}^{\prime}\right), 70.3\left(\mathrm{C}^{\prime}\right), 70.5\left(\mathrm{C}^{\prime}, \mathrm{C} 6\right), 71.2\left(\mathrm{CH}_{2}{ }^{\mathrm{Bn}}\right)$, $71.8\left(\mathrm{C}^{\prime}\right), 71.9,72.3\left(2 \mathrm{CH}_{2}{ }^{\mathrm{Bn}}\right), 72.5(\mathrm{C} 5), 73.1,73.2,73.7$ (3 $\left.\mathrm{CH}_{2}{ }^{\mathrm{Bn}}\right), 75.4,75.4,75.5\left(\mathrm{C} 2, \mathrm{C} 4, \mathrm{C}^{\prime}\right), 77.0\left(\mathrm{C}^{\prime}\right), 80.1(\mathrm{C} 3), 85.6$ (C1), 100.4 (C1'), 127.3, 127.5, 127.5, 127.6, 127.6, 127.6, 127.8, $127.9,127.9,128.1,128.2,128.3,128.4,128.4,128.5,128.7,129.2$ $132.2\left(\mathrm{CH}_{\text {arom }}\right), 134.2,137.9,137.9,138.4,138.6,138.6,138.9$ $\left(\mathrm{C}_{\text {arom }}\right), 172.0\left(\mathrm{C}=\mathrm{O}^{i \mathrm{Val}}\right)$.

HRMS (ESI): $m / z[\mathrm{M}+\mathrm{Na}]^{+}$calcd for $\mathrm{C}_{65} \mathrm{H}_{70} \mathrm{NaO}_{11} \mathrm{~S}: 1081.4537$; found: 1081.4556 .

\section{(2,3,6-Tri- $O$-benzyl-4- $O$-chloroacetyl- $\alpha$-D-mannopyranosyl)-} $(1 \rightarrow 4)-2,3,6$-tri- $O$-benzyl- $\alpha$-D-mannopyranosyl Trichloroacetimidate (12)

Thioglycoside $11(620 \mathrm{mg}, 0.58 \mathrm{mmol})$ was dissolved in acetone$\mathrm{H}_{2} \mathrm{O}(19: 1,12 \mathrm{~mL})$ and cooled to $0{ }^{\circ} \mathrm{C}$. After the addition of NBS (313 $\mathrm{mg}, 1.76 \mathrm{mmol}, 3$ equiv), the mixture was stirred for $30 \mathrm{~min}$ at $0{ }^{\circ} \mathrm{C}$. The reaction was stopped by the addition of $10 \%$ aq $\mathrm{Na}_{2} \mathrm{~S}_{2} \mathrm{O}_{3}$ soln $(1 \mathrm{~mL})$, diluted with EtOAc $(150 \mathrm{~mL})$, and washed with sat. aq $\mathrm{NaHCO}_{3}$ soln-brine $(1: 1,50 \mathrm{~mL})$. The organic phase was dried $\left(\mathrm{MgSO}_{4}\right)$, evaporated, and the residue was purified by flash chromatography (PE-EtOAc, 3:1, 2:1) to afford the corresponding lactol (460 mg, 81\%) as a colorless solid; $R_{f}=0.45$ (PE-EtOAc, 4:1).

${ }^{1} \mathrm{H}$ NMR $\left(500 \mathrm{MHz}, \mathrm{DMSO}-d_{6}\right): \delta=0.81$ and $0.82\left(2 \mathrm{~d},{ }^{3} J=6.6 \mathrm{~Hz}\right.$, each $3 \mathrm{H}, 2 \mathrm{CH}_{3}{ }^{i \mathrm{Val}}$ ), 1.88 (septet, $\left.{ }^{3} J=6.7 \mathrm{~Hz}, 1 \mathrm{H}, \mathrm{CH}^{i \mathrm{Val}}\right), 2.06(\mathrm{~d}$, $\left.{ }^{3} J=6.9 \mathrm{~Hz}, 2 \mathrm{H}, \mathrm{CH}_{2}{ }^{i \mathrm{Val}}\right), 3.28\left(\mathrm{dd},{ }^{2} J=10.9,{ }^{3} J_{5^{\prime}, 6^{\prime} \mathrm{a}}=2.8 \mathrm{~Hz}, 1 \mathrm{H}\right.$, $\left.\mathrm{H}^{\prime}{ }_{\mathrm{a}}\right), 3.30-3.33\left(\mathrm{~m}, 1 \mathrm{H}, \mathrm{H}^{\prime}{ }_{\mathrm{b}}\right), 3.62\left(\mathrm{dd},{ }^{2} J=10.8,{ }^{3} J_{5,6 \mathrm{a}}=5.0 \mathrm{~Hz}\right.$ $1 \mathrm{H}, \mathrm{H6}_{\mathrm{a}}$ ), $3.67\left(\mathrm{dd},{ }^{2} J=10.7,{ }^{3} J_{5,6 \mathrm{~b}}=1.8 \mathrm{~Hz}, 1 \mathrm{H}, \mathrm{H6}_{\mathrm{b}}\right), 3.72(\mathrm{dd}$, $\left.{ }^{3} J_{2^{\prime}, 3^{\prime}}=2.9,{ }^{3} J_{3^{\prime}, 4^{\prime}}=9.8 \mathrm{~Hz}, 1 \mathrm{H}, \mathrm{H} 3^{\prime}\right), 3.75\left(\mathrm{ddd},{ }^{3} J_{5^{\prime}, 6^{\prime} \mathrm{a}}=3.1\right.$, $\left.{ }^{3} J_{5^{\prime}, 6^{\prime} \mathrm{b}}=4.6,{ }^{3} J_{4^{\prime}, 5^{\prime}}=10.0 \mathrm{~Hz}, 1 \mathrm{H}, \mathrm{H} 5^{\prime}\right), 3.84\left(\mathrm{dd},{ }^{3} J_{1^{\prime}, 2^{\prime}}=2.2\right.$, $\left.{ }^{3} J_{2^{\prime}, 3^{\prime}}=2.9 \mathrm{~Hz}, 1 \mathrm{H}, \mathrm{H} 2^{\prime}\right), 3.85-3.90(\mathrm{~m}, 3 \mathrm{H}, \mathrm{H} 5, \mathrm{H} 2, \mathrm{H} 3), 3.93(\mathrm{dd}$, $\left.{ }^{3} J_{3,4}=9.2,{ }^{3} J_{4,5}=9.5 \mathrm{~Hz}, 1 \mathrm{H}, \mathrm{H} 4\right), 4.18-4.65\left(\mathrm{~m}, 12 \mathrm{H}, 6 \mathrm{CH}_{2}{ }^{\mathrm{Bn}}\right)$, $5.17\left(\mathrm{dd},{ }^{3} J_{1,2}=2.2,{ }^{3} J_{1, \mathrm{OH}}=4.1 \mathrm{~Hz}, 1 \mathrm{H}, \mathrm{H} 1\right), 5.19\left(\mathrm{dd},{ }^{3} J_{3^{\prime}, 4^{\prime}}=9.9\right.$, $\left.{ }^{3} J_{4^{\prime}, 5^{\prime}}=10.0 \mathrm{~Hz}, 1 \mathrm{H}, \mathrm{H} 4^{\prime}\right), 5.30\left(\mathrm{~d},{ }^{3} J_{1^{\prime}, 2^{\prime}}=1.9 \mathrm{~Hz}, 1 \mathrm{H}, \mathrm{H} 1^{\prime}\right), 6.73$ (d, $\left.{ }^{3} J_{1, \mathrm{OH}}=4.3 \mathrm{~Hz}, 1 \mathrm{H}, 1-\mathrm{OH}\right), 7.08-7.38\left(\mathrm{~m}, 30 \mathrm{H}, \mathrm{CH}_{\text {arom }}\right)$.

${ }^{13} \mathrm{C} \mathrm{NMR}\left(126 \mathrm{MHz}, 300 \mathrm{~K}\right.$, DMSO- $\left.d_{6}\right): \delta=22.0,22.0\left(2 \mathrm{CH}_{3}{ }^{i \mathrm{Val}}\right)$, $24.9\left(\mathrm{CH}^{i \mathrm{Val}}\right), 42.6\left(\mathrm{CH}_{2}{ }^{i \mathrm{Val}}\right), 67.4\left(\mathrm{C}^{\prime}\right), 68.9\left(\mathrm{C}^{\prime}\right), 69.9(\mathrm{C} 6), 70.0$ $\left(\mathrm{CH}_{2}{ }^{\mathrm{Bn}}\right), 70.0$ (C5), 70.5 (C5'), 70.5, 71.5, 71.6, 72.2, 72.4 (5 $\left.\mathrm{CH}_{2}{ }^{\mathrm{Bn}}\right), 73.6(\mathrm{C} 4), 74.6(\mathrm{C} 2), 74.8\left(\mathrm{C}^{\prime}\right), 76.4\left(\mathrm{C}^{\prime}\right), 79.4(\mathrm{C} 3), 90.9$ (C1), 98.7 (C1'), 127.0, 127.2, 127.3, 127.3, 127.3, 127.3, 127.4, $127.4,127.4,127.5,127.5,128.0,128.1,128.1,128.1,128.1,128.2$ $\left(\mathrm{CH}_{\text {arom }}\right), 138.1,138.2,138.3,138.3,138.4,138.7\left(\mathrm{C}_{\text {arom }}\right), 171.1$ $\left(\mathrm{C}=\mathrm{O}^{i \mathrm{Val}}\right)$.

HRMS (ESI): $m / z[\mathrm{M}+\mathrm{Na}]^{+}$calcd for $\mathrm{C}_{59} \mathrm{H}_{66} \mathrm{NaO}_{12}: 989.4452$; found: 989.4431.

The lactol $(110 \mathrm{mg}, 114 \mu \mathrm{mol})$ and trichloroacetonitrile $(51 \mu \mathrm{L}$, $512 \mu \mathrm{mol}, 4.5$ equiv) were dissolved in $\mathrm{CH}_{2} \mathrm{Cl}_{2}(2 \mathrm{~mL})$ under an atmosphere of argon. At $0^{\circ} \mathrm{C}$, DBU $(5 \mu \mathrm{L}, 34 \mu \mathrm{mol}, 0.3$ equiv $)$ was added. After stirring for $30 \mathrm{~min}$, the solvent was evaporated and the crude product was purified by flash chromatography (PE-EtOAc, $6: 1,4: 1)$ to afford trichloroacetimidate $\mathbf{1 2}(100 \mathrm{mg}, 79 \%)$ as a colorless oil, which was used directly in the glycosylation reactions; $R_{f}=0.48$ (PE-EtOAc, 4:1).

HRMS (ESI): $m / z[\mathrm{M}+\mathrm{Na}]^{+}$calcd for $\mathrm{C}_{61} \mathrm{H}_{66} \mathrm{Cl}_{3} \mathrm{NNaO}_{12}$ : 1132.3543; found: 1132.3522 (correct isotope pattern).

\section{Alloc-L-(3S)-BmePhe-D-Tyr-\{O-[2,3,6-tri- $O$-benzyl-4- $O$ -} $\left(2^{\prime}, 3^{\prime}, 6^{\prime}\right.$-tri- $O$-benzyl-4'-O-isovaleroyl- $\alpha$-D-mannopyranosyl)- $\alpha$ D-mannopyranosyl]\}-OMe (14)

Trichloroacetimidate $12(100 \mathrm{mg}, 90 \mu \mathrm{mol}, 1.3$ equiv) and dipeptide 13 (30 mg, $68 \mu$ mol, 1 equiv) were dissolved in $\mathrm{CH}_{2} \mathrm{Cl}_{2}(2 \mathrm{~mL})$. The mixture was cooled to $-30{ }^{\circ} \mathrm{C}$ and $\mathrm{BF}_{3} \cdot \mathrm{OEt}_{2}(7 \mu \mathrm{L}, 54 \mu \mathrm{mol}, 0.6$ equiv based on donor 12) was added. After $1 \mathrm{~h}$ at this temperature, the reaction was quenched by the addition of $\mathrm{Et}_{3} \mathrm{~N}(0.2 \mathrm{~mL})$ and purified directly by flash chromatography (PE-EtOAc, 2:1) to afford the dimannosyl dipeptide $14(57 \mathrm{mg}, 60 \%)$ as a colorless amorphous solid; $R_{f}=0.20$ (PE-EtOAc, 2:1).
${ }^{1} \mathrm{H}$ NMR $\left(500 \mathrm{MHz}\right.$, acetone- $\left.d_{6}\right): \delta=0.86,0.88\left(2 \mathrm{~d},{ }^{3} J=6.7 \mathrm{~Hz}\right.$, each $\left.3 \mathrm{H}, 2 \mathrm{CH}_{3}{ }^{i \mathrm{Val}}\right), 1.14\left(\mathrm{~d},{ }^{3} J_{\beta, \mathrm{Me}}=7.1 \mathrm{~Hz}, 3 \mathrm{H}, \mathrm{CH}_{3}{ }^{\text {mePhe }}\right), 1.98$ (septet, $\left.{ }^{3} \mathrm{~J}=6.7 \mathrm{~Hz}, 1 \mathrm{H}, \mathrm{CH}^{i \mathrm{Val}}\right), 2.08-2.12\left(\mathrm{~m}, 2 \mathrm{H}, \mathrm{CH}_{2}{ }^{i \mathrm{Val}}\right), 2.97$ $\left(\mathrm{dd},{ }^{2} J=14.0,{ }^{3} J_{\alpha, \beta \mathrm{a}}=9.2 \mathrm{~Hz}, 1 \mathrm{H}, \beta-\mathrm{H}_{\mathrm{a}}^{\mathrm{Tyr}}\right), 3.09-3.17(\mathrm{~m}, 1 \mathrm{H}, \beta-$ $\left.\mathrm{H}^{\text {mePhe }}\right), 3.16\left(\mathrm{dd},{ }^{2} J=14.2,{ }^{3} J_{\alpha, \beta b}=5.2 \mathrm{~Hz}, 1 \mathrm{H}, \beta-\mathrm{H}_{\mathrm{b}}{ }^{\mathrm{Tyr}}\right), 3.41-3.48$ (m, 2 H, H6'), 3.62-3.71 (m, 2 H, H6), $3.66\left(\mathrm{~s}, 3 \mathrm{H}, \mathrm{OCH}_{3}\right), 3.79(\mathrm{~m}$, $1 \mathrm{H}, \mathrm{H} 5), 3.87\left(\mathrm{dd},{ }^{3} J_{2^{\prime}, 3^{\prime}}=2.9,{ }^{3} J_{3^{\prime}, 4^{\prime}}=9.8 \mathrm{~Hz}, 1 \mathrm{H}, \mathrm{H} 3^{\prime}\right), 3.90(\mathrm{~m}, 1$ H, H5'), $3.94\left(\mathrm{dd},{ }^{3} J_{1^{\prime}, 2^{\prime}}=2.1,{ }^{3} J_{2^{\prime}, 3^{\prime}}=3.1 \mathrm{~Hz}, 1 \mathrm{H}, \mathrm{H} 2^{\prime}\right), 4.10(\mathrm{dd}$, $\left.{ }^{3} J_{2,3}=3.1, \quad{ }^{3} J_{3,4}=9.2 \mathrm{~Hz}, 1 \mathrm{H}, \mathrm{H} 3\right), 4.19\left(\mathrm{dd},{ }^{3} J_{1,2}=2.4\right.$, $\left.{ }^{3} J_{2,3}=3.1 \mathrm{~Hz}, 1 \mathrm{H}, \mathrm{H} 2\right), 4.25\left(\mathrm{t},{ }^{3} J_{3,4}={ }^{3} J_{4,5}=9.4 \mathrm{~Hz}, 1 \mathrm{H}, \mathrm{H} 4\right)$, $4.30-4.80\left(\mathrm{~m}, 14 \mathrm{H}, 6 \times \mathrm{CH}_{2}{ }^{\mathrm{Bn}}, \mathrm{CH}_{2}{ }^{\mathrm{All}}\right), 4.32-4.38(\mathrm{~m}, 1 \mathrm{H}, \alpha-$ $\left.\mathrm{H}^{\text {mePhe }}\right), 4.64-4.75\left(\mathrm{~m}, 1 \mathrm{H}, \alpha-\mathrm{H}^{\mathrm{Tyr}}\right), 5.05-5.11,5.13-5.20(2 \mathrm{~m}$, each $\left.1 \mathrm{H},=\mathrm{CH}_{2}{ }^{\mathrm{All}}\right), 5.38\left(\mathrm{t},{ }^{3} J_{3^{\prime}, 4^{\prime}}={ }^{3} J_{4^{\prime}, 5^{\prime}}=9.9 \mathrm{~Hz}, 1 \mathrm{H}, \mathrm{H} 4^{\prime}\right), 5.40(\mathrm{~d}$, $\left.{ }^{3} J_{1^{\prime}, 2^{\prime}}=1.7 \mathrm{~Hz}, 1 \mathrm{H}, \mathrm{H1} 1^{\prime}\right), 5.69\left(\mathrm{~d},{ }^{3} J_{1,2}=1.7 \mathrm{~Hz}, 1 \mathrm{H}, \mathrm{H1}\right), 5.77-$ $5.86\left(\mathrm{~m}, 1 \mathrm{H},=\mathrm{CH}^{\mathrm{All}}\right), 5.92\left(\mathrm{br} \mathrm{d},{ }^{3} J_{\alpha, \mathrm{NH}}=8.9 \mathrm{~Hz}, 1 \mathrm{H}, \mathrm{NH}^{\mathrm{mePhe}}\right)$, $6.96-7.51\left(\mathrm{~m}, 39 \mathrm{H}, \mathrm{H}_{\text {arom }}\right), 7.66\left(\mathrm{brd},{ }^{3} J_{\alpha, \mathrm{NH}}=8.4 \mathrm{~Hz}, 1 \mathrm{H}, \mathrm{NH}^{\mathrm{Tyr}}\right)$.

${ }^{13} \mathrm{C}$ NMR (126 MHz, acetone- $\left.d_{6}\right): \delta=19.1\left(\mathrm{CH}_{3}{ }^{\mathrm{mePhe}}\right), 22.7$ $\left.\mathrm{CH}_{3}{ }^{i \mathrm{Val}}\right), 26.1\left(\mathrm{CH}^{i \mathrm{Val}}\right), 37.6\left(\mathrm{C}-\beta^{\mathrm{Tyr}}\right), 42.9\left(\mathrm{C}-\beta^{\text {mePhe }}\right), 43.9\left(\mathrm{CH}_{2}{ }^{i \mathrm{Val}}\right)$, $52.3\left(\mathrm{OCH}_{3}\right), 54.8\left(\mathrm{C}-\alpha^{\mathrm{Tyr}}\right), 60.7\left(\mathrm{C}-\alpha^{\mathrm{mePhe}}\right), 65.7\left(\mathrm{OCH}_{2}{ }^{\mathrm{All}}\right), 69.1$ (C4'), 70.6 (C6), $70.9\left(\mathrm{C} 6^{\prime}\right), 71.7,72.1\left(2 \times \mathrm{CH}_{2}{ }^{\mathrm{Bn}}\right), 72.2\left(\mathrm{C}^{\prime}\right), 73.0$ $\left(\mathrm{CH}_{2}{ }^{\mathrm{Bn}}\right), 73.1(\mathrm{C} 5), 73.3,73.5,73.9\left(4 \times \mathrm{CH}_{2}{ }^{\mathrm{Bn}}\right), 75.0(\mathrm{C} 4), 75.0$ (C2), $76.4\left(\mathrm{C}^{\prime}\right), 78.0\left(\mathrm{C}^{\prime}\right), 80.7$ (C3), $97.3\left(\mathrm{Cl}^{\prime}\right), 100.7$ (C1), 117.1 $\left(=\mathrm{CH}_{2}{ }^{\mathrm{All}}\right), 117.8\left(2 \mathrm{~m}-\mathrm{CH}_{\text {arom }}{ }^{\text {Tyr }}\right), 127.4,128.0,128.1,128.1,128.2$, $128.2,128.3,128.3,128.4,128.5,128.5,128.6,128.6,128.6,128.7$, $128.8,128.9,128.9,129.0,129.0,129.0,129.1,129.2,129.3,131.3$, $131.3\left(\mathrm{CH}_{\text {arom }}\right), 131.3\left(o-\mathrm{CH}_{\text {arom }}{ }^{\mathrm{Tyr}}\right), 131.9\left(i-\mathrm{C}_{\text {arom }}{ }^{\mathrm{Tr}}\right), 134.3$ $\left(=\mathrm{CH}^{\mathrm{All}}\right), 139.4,139.6,139.6,139.6,139.8,139.9,143.4\left(i-\mathrm{C}_{\text {arom }}\right)$, $156.5\left(p-\mathrm{C}_{\text {arom }}{ }^{\text {Tyr }}, \mathrm{C}=\mathrm{O}^{\text {carbamate }}\right), 171.7\left(\mathrm{C}=\mathrm{O}^{\text {amide }}\right), 172.1\left(\mathrm{C}=\mathrm{O}^{i \mathrm{Val}}\right)$, 172.5 (COOMe).

HRMS (ESI): $m / z[\mathrm{M}+\mathrm{H}]^{+}$calcd for $\mathrm{C}_{83} \mathrm{H}_{93} \mathrm{~N}_{2} \mathrm{O}_{17}: 1389.6474$; found: 1389.6472 .

\section{Dimannosylated Linear Hexapeptide 16}

Trichloroacetimidate 12 (160 mg, $144 \mu \mathrm{mol}, 1.4$ equiv) and linear hexapeptide 15 (126 mg, $101 \mu \mathrm{mol}, 1$ equiv) were dissolved in $\mathrm{CH}_{2} \mathrm{Cl}_{2}(1.5 \mathrm{~mL})$ and cooled to $-30^{\circ} \mathrm{C} . \mathrm{BF}_{3} \cdot \mathrm{OEt}_{2}(62 \mu \mathrm{L}, 504 \mu \mathrm{mol}$, 3.5 equiv based on donor 12) was added dropwise, and the reaction was stirred at this temperature for $40 \mathrm{~min}$. The reaction was stopped by the addition of $\mathrm{Et}_{3} \mathrm{~N}(0.2 \mathrm{~mL})$, and the mixture was diluted with $\mathrm{CH}_{2} \mathrm{Cl}_{2}(30 \mathrm{~mL})$ and washed with sat. aq $\mathrm{NH}_{4} \mathrm{Cl}-\mathrm{H}_{2} \mathrm{O}(1: 1,15 \mathrm{~mL})$ and sat. aq $\mathrm{NaHCO}_{3}(15 \mathrm{~mL})$. The organic phase was dried $\left(\mathrm{MgSO}_{4}\right)$ and evaporated, and the residue was purified by flash chromatography $\left(\mathrm{CH}_{2} \mathrm{Cl}_{2}-\mathrm{MeOH}, 60: 1,40: 1,20: 1\right)$. This afforded unreacted acceptor $15(23 \mathrm{mg}, 18 \%)$ and the glycosylated hexapeptide $16(137 \mathrm{mg}, 62 \%)$ as a colorless solid; $R_{f}=0.50\left(\mathrm{CH}_{2} \mathrm{Cl}_{2}-\right.$ $\mathrm{MeOH}, 20: 1)$.

$[\alpha]_{\mathrm{D}}^{22}+33.1\left(c 1.0, \mathrm{CHCl}_{3}\right)$.

${ }^{1} \mathrm{H}$ NMR $\left(500 \mathrm{MHz}, 350 \mathrm{~K}\right.$, DMSO- $\left.d_{6}\right): \delta=0.84,0.85\left(2 \mathrm{~d},{ }^{3} J=6.6\right.$ $\mathrm{Hz}$, each $\left.3 \mathrm{H}, 2 \mathrm{CH}_{3}{ }^{i \mathrm{Val}}\right), 0.92\left(\mathrm{~d},{ }^{3} J_{\beta, \mathrm{Me}}=7.1 \mathrm{~Hz}, 3 \mathrm{H}, \mathrm{CH}_{3}{ }^{\text {mePhe }}\right)$, 1.38 (br s, $3 \mathrm{H}, \mathrm{CH}_{3}{ }^{i}$-Pr $), 1.42$ (br s, $9 \mathrm{H}, \mathrm{CH}_{3}{ }^{\mathrm{Boc}}$ ), 1.44 (br s, $12 \mathrm{H}$, $\left.\mathrm{CH}_{3}{ }^{i-\mathrm{Pr}}, \mathrm{CH}_{3}{ }^{\mathrm{Boc}}\right), 1.49$ (br s, $\left.3 \mathrm{H}, \mathrm{CH}_{3}{ }^{i} \mathrm{Pr}\right), 1.51$ (br s, $3 \mathrm{H}, \mathrm{CH}_{3}{ }^{i-\mathrm{Pr}}$ ), 1.91 (septet, $\left.{ }^{3} J=6.6 \mathrm{~Hz}, 1 \mathrm{H}, \mathrm{CH}^{i \mathrm{Val}}\right), 2.07\left(\mathrm{~d},{ }^{3} J=6.8 \mathrm{~Hz}, 2 \mathrm{H}\right.$, $\left.\mathrm{CH}_{2}{ }^{i \mathrm{Val}}\right), 2.79\left(\mathrm{dd},{ }^{2} J=14.0,{ }^{3} J_{\alpha, \beta \mathrm{a}}=9.7 \mathrm{~Hz}, 1 \mathrm{H}, \beta-\mathrm{H}_{\mathrm{a}}{ }^{\mathrm{Tyr}}\right), 2.90(\mathrm{dq}$, $\left.{ }^{3} J_{\beta, \mathrm{Me}}=6.8,{ }^{3} J_{\alpha, \beta}=7.5 \mathrm{~Hz}, 1 \mathrm{H}, \beta-\mathrm{H}^{\mathrm{mePhe}}\right), 3.11\left(\mathrm{dd},{ }^{2} J=14.1,{ }^{3} J_{\alpha, \beta \mathrm{b}}=\right.$ $\left.4.3 \mathrm{~Hz}, 1 \mathrm{H}, \beta-\mathrm{H}_{\mathrm{b}}{ }^{\mathrm{Tyr}}\right), 3.28-3.44\left(\mathrm{~m}, 2 \mathrm{H}, \mathrm{H6}_{\mathrm{a}}, \mathrm{H6}^{\prime}{ }_{\mathrm{a}}\right), 3.51-3.60(\mathrm{~m}$, $\left.2 \mathrm{H}, \mathrm{H}_{\mathrm{b}}, \mathrm{H}^{\prime}{ }_{\mathrm{b}}\right), 3.61\left(\mathrm{~s}, 3 \mathrm{H}, \mathrm{OCH}_{3}\right), 3.67-3.72\left(\mathrm{~m}, 2 \mathrm{H}, \beta-\mathrm{H}_{2}{ }^{\mathrm{Ser}}\right)$, 3.71-3.75 (m, $1 \mathrm{H}, \mathrm{H} 5), 3.75-3.80\left(\mathrm{~m}, 3 \mathrm{H}, \mathrm{H} 3^{\prime}, \mathrm{H} 5^{\prime}, \delta-\mathrm{H}_{\mathrm{a}}^{\mathrm{L}-\mathrm{Hep}}\right)$, 3.82-3.87 (m, $\left.2 \mathrm{H}, \mathrm{H} 2^{\prime}, \delta-\mathrm{H}_{\mathrm{a}}^{\mathrm{D}-\mathrm{Hep}}\right), 3.87-3.94\left(\mathrm{~m}, 4 \mathrm{H}, \gamma-\mathrm{H}_{\mathrm{a}}^{\mathrm{D}-\mathrm{Hep}}, \gamma-\right.$ $\left.\mathrm{H}_{\mathrm{a}}^{\mathrm{L}-\mathrm{Hep}}, \mathrm{CH}_{2}{ }^{\mathrm{Gly}}\right), 3.97-4.03\left(\mathrm{~m}, 2 \mathrm{H}, \mathrm{H} 3, \beta-\mathrm{H}^{\mathrm{L}-\mathrm{Hep}}\right), 4.08\left(\mathrm{t},{ }^{3} J_{3,4}=\right.$ $\left.{ }^{3} J_{4,5}=9.4 \mathrm{~Hz}, 1 \mathrm{H}, \mathrm{H} 4\right), 4.10\left(\mathrm{dd},{ }^{3} J_{1,2}=2.4,{ }^{3} J_{2,3}=3.0 \mathrm{~Hz}, 1 \mathrm{H}, \mathrm{H} 2\right)$, $4.09-4.13\left(\mathrm{~m}, 2 \mathrm{H}, \delta-\mathrm{H}_{\mathrm{b}}{ }^{\mathrm{D}-\mathrm{Hep}}, \delta-\mathrm{H}_{\mathrm{b}}^{\mathrm{L}-\mathrm{Hep}}\right), 4.22\left(\mathrm{t},{ }^{3} J=9.0 \mathrm{~Hz}, 1 \mathrm{H}, \alpha-\right.$ $\left.\mathrm{H}^{\mathrm{mePhe}}\right), 4.25-4.30\left(\mathrm{~m}, 1 \mathrm{H}, \beta-\mathrm{H}^{\mathrm{D}-\mathrm{Hep}}\right), 4.26-4.52\left(\mathrm{~m}, 13 \mathrm{H}, \mathrm{OCH}_{2}{ }^{\mathrm{All}}\right.$, $\left.5.5 \mathrm{OCH}_{2}{ }^{\mathrm{Bn}}\right), 4.33-4.37\left(\mathrm{~m}, 1 \mathrm{H}, \alpha-\mathrm{H}^{\mathrm{D}-\mathrm{Hep}}\right), 4.45-4.48(\mathrm{~m}, 1 \mathrm{H}, \alpha-$ $\left.\mathrm{H}^{\mathrm{L}-\mathrm{Hep}}\right), 4.59$ (ddd, ${ }^{3} J_{\alpha, \beta \mathrm{a}}=5.7,{ }^{3} J_{\alpha, \mathrm{NH}}=7.5,{ }^{3} J_{\alpha, \beta \mathrm{b}}=8.0 \mathrm{~Hz}, 1 \mathrm{H}, \alpha-$ $\mathrm{H}_{\mathrm{Ser}}$ ), 4.63-4.75 (m, $\left.4 \mathrm{H}, 1.5 \mathrm{OCH}_{2}^{\mathrm{Bn}}, \alpha-\mathrm{H}^{\mathrm{Tyr}}\right), 4.89$ (br d, ${ }^{3} J=5.7$ $\left.\mathrm{Hz}, 1 \mathrm{H}, \mathrm{OH}^{\mathrm{L}-\mathrm{Hep}}\right), 4.91$ (br s, $\left.1 \mathrm{H}, \mathrm{OH}^{\mathrm{D}-\mathrm{Hep}}\right), 5.04-5.16(\mathrm{~m}, 2 \mathrm{H}$, $\left.=\mathrm{CH}_{2}{ }^{\mathrm{All}}\right), 5.21\left(\mathrm{t},{ }^{3} J_{3^{\prime}, 4^{\prime}}={ }^{3} J_{4^{\prime}, 5^{\prime}}=9.8 \mathrm{~Hz}, 1 \mathrm{H}, \mathrm{H} 4^{\prime}\right), 5.29\left(\mathrm{~d},{ }^{3} J_{1^{\prime}, 2^{\prime}}=\right.$ $\left.2.2 \mathrm{~Hz}, 1 \mathrm{H}, \mathrm{H} 1^{\prime}\right), 5.60\left(\mathrm{~d},{ }^{3} J_{1,2}=2.2 \mathrm{~Hz}, 1 \mathrm{H}, \mathrm{H1}\right), 5.73-5.79(\mathrm{~m}, 1$ 
$\left.\mathrm{H},=\mathrm{CH}^{\mathrm{All}}\right), 6.42\left(\right.$ br s, $\left.1 \mathrm{H}, \mathrm{NH}^{\mathrm{mePhe}}\right), 6.97-7.40\left(\mathrm{~m}, 44 \mathrm{H}, \mathrm{H}_{\mathrm{arom}}\right)$, 7.98 (br s, $1 \mathrm{H}, \mathrm{NH}^{\mathrm{Ser}}$ ), 7.99 (br d, ${ }^{3} J_{\alpha, \mathrm{NH}}=7.2 \mathrm{~Hz}, 1 \mathrm{H}, \mathrm{NH}^{\mathrm{L}-\mathrm{Hep}}$ ), 8.13 (br t, $\left.{ }^{3} J_{\mathrm{CH} 2 \alpha, \mathrm{NH}}=6.4 \mathrm{~Hz}, 1 \mathrm{H}, \mathrm{NH}^{\mathrm{Gly}}\right), 8.16$ (br s, $\left.1 \mathrm{H}, \mathrm{NH}^{\mathrm{D}-\mathrm{Hep}}\right)$, $8.19\left(\mathrm{br} \mathrm{d},{ }^{3} \mathrm{~J}=6.7 \mathrm{~Hz}, 1 \mathrm{H}, \mathrm{NH}^{\mathrm{Tyr}}\right.$ ).

${ }^{13} \mathrm{C}$ NMR: $\left(126 \mathrm{MHz}, 350 \mathrm{~K}\right.$, DMSO- $\left.d_{6}\right): \delta=18.3\left(\mathrm{CH}_{3}{ }^{\mathrm{mePhe}}\right), 21.6$ $\left(2 \mathrm{CH}_{3}{ }^{i \mathrm{Val}}\right), 24.1\left(2 \mathrm{CH}_{3}{ }^{i-\mathrm{Pr}}\right), 24.5\left(\mathrm{CH}^{i \mathrm{Val}}\right), 26.1\left(2 \mathrm{CH}_{3}{ }^{i-\mathrm{Pr}}\right), 27.7$ $\left(\mathrm{CH}_{3}{ }^{\mathrm{Boc}}\right), 27.8\left(\mathrm{CH}_{3}{ }^{\mathrm{Boc}}\right), 36.6\left(\mathrm{C}-\beta^{\mathrm{Tyr}}\right), 40.5\left(\mathrm{CH}_{2}{ }^{\mathrm{Gly}}\right), 41.2(\mathrm{C}-$ $\left.\beta^{\text {mePhe }}\right), 42.4\left(\mathrm{CH}_{2}{ }^{i \mathrm{Val}}\right), 51.1\left(\mathrm{OCH}_{3}\right), 52.6\left(\mathrm{C}-\alpha^{\mathrm{Ser}}\right), 54.0\left(\mathrm{C}-\alpha^{\mathrm{Tyr}}\right)$, $54.9\left(\mathrm{C}-\alpha^{\mathrm{L}-\mathrm{Hep}}\right), 56.6\left(\mathrm{C}-\alpha^{\mathrm{D}-H e p}\right), 58.1,58.4\left(\mathrm{C}-\gamma^{\mathrm{D}-H e p}, \mathrm{C}-\gamma^{\mathrm{L}-\mathrm{Hep}}\right), 59.6$ $\left(\mathrm{C}-\alpha^{\text {mePhe }}\right), 62.4\left(\mathrm{C}-\delta^{\text {D-Hep }}\right), 62.5\left(\mathrm{C}-\delta^{\mathrm{L}-\mathrm{Hep}}\right), 64.1\left(\mathrm{OCH}_{2}{ }^{\mathrm{Allyl}}\right), 67.5$ $\left(\mathrm{C} 4^{\prime}\right), 69.0$ (2 C, C6, C6 $\left.6^{\prime}\right), 69.4$ (C- $\left.\beta^{\mathrm{Ser}}\right), 69.4\left(\mathrm{C}-\beta^{\mathrm{D}-\mathrm{Hep}}\right), 70.2$ $\left(\mathrm{CH}_{2} \mathrm{Ph}, \mathrm{C}-\beta^{\mathrm{L}-\mathrm{Hep}}\right), 70.4\left(\mathrm{CH}_{2} \mathrm{Ph}\right), 70.5(\mathrm{C} 5), 71.4,71.4,71.6,71.9$ $\left(\mathrm{CH}_{2} \mathrm{Ph}\right), 72.5(\mathrm{C} 4), 73.6(\mathrm{C} 2), 74.9\left(\mathrm{C}^{\prime}\right), 76.2\left(\mathrm{C}^{\prime}, \mathrm{C}^{\prime}\right), 78.7$ (C3), 79.0, $79.1\left(\mathrm{C}_{\mathrm{q}}{ }^{\mathrm{Boc}}\right), 92.7,92.9\left(\mathrm{C}_{\mathrm{q}}{ }^{i-\mathrm{Pr}}\right), 95.9\left(\mathrm{C} 1^{\prime}\right), 98.6(\mathrm{C} 1)$, $116.4\left(=\mathrm{CH}_{2}{ }^{\mathrm{All}}\right), 116.4,125.7,126.7,126.7,126.8,126.8,126.9$, 126.9, 127.0, 127.1, 127.1, 127.2, 127.2, 127.4, 127.6, 127.6, 127.7, $127.7,129.7,127.8,131.4\left(\mathrm{CH}_{\text {arom }}, \mathrm{C}_{\text {arom }}\right), 132.9\left(=\mathrm{CH}^{\mathrm{All}}\right), 137.8$, $137.9,137.9,137.9,138.0,138.1,142.6\left(\mathrm{C}_{\text {arom }}\right), 151.3,151.4$ $\left(\mathrm{C}=\mathrm{O}^{\mathrm{Boc}}\right), 154.2\left(\mathrm{C}=\mathrm{O}^{\mathrm{Alloc}}\right), 154.4\left(p-\mathrm{C}_{\text {arom }}{ }^{\mathrm{Tyr}}\right), 169.3(\mathrm{COOMe})$, $169.4,170.3,170.4\left(\mathrm{C}=\mathrm{O}^{\text {amide }}\right), 170.6\left(\mathrm{C}=\mathrm{O}^{i \mathrm{Val}}\right)$.

HRMS (ESI): $m / z[\mathrm{M}+\mathrm{Na}]^{+}$calcd for $\mathrm{C}_{121} \mathrm{H}_{150} \mathrm{~N}_{8} \mathrm{NaO}_{30}$ : 2219.0389; found: 2219.0402 .

\section{Dimannosyl Cyclopeptide 17}

To a soln of linear hexapeptide $\mathbf{1 6}(81 \mathrm{mg}, 37 \mu \mathrm{mol}, 1$ equiv $)$ in THF (degassed, $0.5 \mathrm{~mL})$ was added morpholine $(16 \mu \mathrm{L}, 184 \mu \mathrm{mol}, 5$ equiv) and $\mathrm{Pd}\left(\mathrm{PPh}_{3}\right)_{4}(9 \mathrm{mg}, 8 \mu \mathrm{mol}, 0.2$ equiv), and the mixture was stirred for $30 \mathrm{~min}$ at r.t. After evaporation of the solvent, the residue was directly purified by flash chromatography $\left(\mathrm{CH}_{2} \mathrm{Cl}_{2}-\right.$ $\mathrm{MeOH}, 40: 1,20: 1,10: 1)$, which afforded the corresponding terminal amine (52 mg, 67\%) as an amorphous solid; $R_{f}=0.30\left(\mathrm{CH}_{2} \mathrm{Cl}_{2}-\right.$ $\mathrm{MeOH}, 20: 1)$.

HRMS (ESI): $m / z[\mathrm{M}+\mathrm{H}]^{+}$calcd for $\mathrm{C}_{117} \mathrm{H}_{147} \mathrm{~N}_{8} \mathrm{O}_{28}: 2113.0358$; found: 2113.0375 .

The amine ( $52 \mathrm{mg}, 25 \mu \mathrm{mol})$ was dissolved in 1,4-dioxane $(0.5 \mathrm{~mL})$ and treated with aq $1 \mathrm{M} \mathrm{LiOH}(50 \mu \mathrm{L}, 50 \mu \mathrm{mol}, 2$ equiv $)$ at $8{ }^{\circ} \mathrm{C}$. After stirring for $90 \mathrm{~min}$, the reaction was stopped by the addition of $2 \mathrm{M} \mathrm{HCl}(38 \mu \mathrm{L}, 75 \mu \mathrm{mol}, 3$ equiv), and the solvents were removed under reduced pressure to afford the $\mathrm{N}$ - and C-terminally deprotected hexapeptide.

HRMS (ESI): $m / z[\mathrm{M}+\mathrm{H}]^{+}$calcd for $\mathrm{C}_{116} \mathrm{H}_{145} \mathrm{~N}_{8} \mathrm{O}_{28}: 2099.0202$; found: 2099.0232 .

The crude residue was dissolved in THF $(25 \mathrm{~mL})$ and cooled with an ice-water bath. Following the addition of solid $\mathrm{NaHCO}_{3}(8 \mathrm{mg}$, $100 \mu \mathrm{mol}, 4$ equiv) and DEPBT ( $22 \mathrm{mg}, 75 \mu \mathrm{mol}, 3$ equiv), the mixture was stirred at r.t. for $4 \mathrm{~d}$. After evaporation of the solvent, the residue was partitioned between EtOAc $(30 \mathrm{~mL})$ and sat. aq $\mathrm{NaHCO}_{3}(20 \mathrm{~mL})$. The organic phase was washed with sat. aq $\mathrm{NaHCO}_{3}(20 \mathrm{~mL})$ and brine $(20 \mathrm{~mL})$, dried $\left(\mathrm{MgSO}_{4}\right)$, and evaporated. Purification of the residue by flash chromatography $\left(\mathrm{CH}_{2} \mathrm{Cl}_{2}-\right.$ $\mathrm{MeOH}, 60: 1,40: 1,20: 1)$ afforded cyclopeptide $17(37 \mathrm{mg}, 72 \%)$ as a colorless, amorphous solid; $R_{f}=0.40\left(\mathrm{CH}_{2} \mathrm{Cl}_{2}-\mathrm{MeOH}, 20: 1\right)$.

$[\alpha]_{\mathrm{D}}^{22}+37.7\left(c 1.0, \mathrm{CHCl}_{3}\right)$.

${ }^{1} \mathrm{H}$ NMR $\left(500 \mathrm{MHz}, 350 \mathrm{~K}\right.$, DMSO- $\left.d_{6}\right): \delta=0.72($ br s, $3 \mathrm{H}$, $\left.\mathrm{CH}_{3}{ }^{\mathrm{mePhe}}\right), 0.84,0.85\left(2 \mathrm{~d},{ }^{3} \mathrm{~J}=6.7 \mathrm{~Hz}\right.$, each $\left.3 \mathrm{H}, 2 \mathrm{CH}_{3}{ }^{i \mathrm{Val}}\right), 1.30(\mathrm{br}$ $\mathrm{s}, 3 \mathrm{H}, \mathrm{CH}_{3}{ }^{i-\mathrm{Pr}}$ ), 1.41 (br s, $9 \mathrm{H}, \mathrm{CH}_{3}{ }^{\mathrm{Boc}}$ ), $1.42\left(\mathrm{br} \mathrm{s}, 3 \mathrm{H}, \mathrm{CH}_{3}{ }^{i} \mathrm{Pr}\right.$ ), 1.48 (br s, $9 \mathrm{H}, \mathrm{CH}_{3}{ }^{\mathrm{Boc}}$ ), 1.49 (br s, $3 \mathrm{H}, \mathrm{CH}_{3}{ }^{i-\mathrm{Pr}}$ ), 1.56 (br s, $3 \mathrm{H}, \mathrm{CH}_{3}{ }^{i-\mathrm{Pr}}$ ), 1.91 (septet, $\left.{ }^{3} \mathrm{~J}=6.7 \mathrm{~Hz}, 1 \mathrm{H}, \mathrm{CH}^{i \mathrm{Val}}\right), 2.04-2.08\left(\mathrm{~m}, 2 \mathrm{H} \mathrm{CH}_{2}{ }^{i \mathrm{Val}}\right)$, $2.76\left(\mathrm{dd},{ }^{2} J=14.0,{ }^{3} J_{\alpha \beta \mathrm{a}}=10.2 \mathrm{~Hz}, 1 \mathrm{H}, \beta-\mathrm{H}_{\mathrm{a}}^{\mathrm{Tyr}}\right), 2.90\left(\mathrm{dq},{ }^{3} J_{\beta \mathrm{Me}}=\right.$ $\left.6.7,{ }^{3} J_{\alpha, \beta}=7.1 \mathrm{~Hz}, 1 \mathrm{H}, \beta-\mathrm{H}^{\mathrm{mePhe}}\right), 3.22\left(\mathrm{br} \mathrm{d},{ }^{2} J=13.8 \mathrm{~Hz}, 1 \mathrm{H}, \beta-\right.$ $\left.\mathrm{H}_{\mathrm{b}}^{\mathrm{Tyr}}\right), 3.34\left(\mathrm{dd},{ }^{2} J=11.0,{ }^{3} J_{5,6}=3.0 \mathrm{~Hz}, 1 \mathrm{H}, \mathrm{H} 6_{\mathrm{a}}^{\prime}\right), 3.37\left(\mathrm{~d},{ }^{2} J=\right.$ $\left.11.0,{ }_{5,6}^{3} J_{5,6}=4.6 \mathrm{~Hz}, 1 \mathrm{H}, \mathrm{H6}_{\mathrm{b}}^{\prime}\right), 3.42\left(\mathrm{brd},{ }^{2} J=11.0 \mathrm{~Hz}, 1 \mathrm{H}, \mathrm{CH}_{\mathrm{a}}{ }^{\mathrm{Gly}}\right)$, $3.57-3.63(\mathrm{~m}, 2 \mathrm{H}, 6 \mathrm{H}), 3.65\left(\mathrm{dd},{ }^{2} J=9.5,{ }^{3} J=8.0 \mathrm{~Hz}, 1 \mathrm{H}, \beta-\right.$ $\left.\mathrm{CH}_{\mathrm{a}}^{\mathrm{Ser}}\right), 3.73-3.80\left(\mathrm{~m}, 5 \mathrm{H}, \mathrm{CH}_{\mathrm{b}}^{\mathrm{Gly}}, \beta-\mathrm{H}_{\mathrm{b}}{ }^{\text {Ser }}, \mathrm{H} 5, \mathrm{H}^{\prime}, \mathrm{H} 5^{\prime}\right), 3.80$ $3.87\left(\mathrm{~m}, 5 \mathrm{H}, \delta-\mathrm{H}_{\mathrm{a}}{ }^{\mathrm{D}-\mathrm{Hep}}, \delta-\mathrm{H}_{\mathrm{a}}^{\mathrm{L}-\mathrm{Hep}}, \gamma-\mathrm{H}_{\mathrm{a}}{ }^{\mathrm{D}-\mathrm{Hep}}, \gamma-\mathrm{H}_{\mathrm{a}}^{\mathrm{L}-\mathrm{Hep}}, \mathrm{H} 2^{\prime}\right), 3.89(\mathrm{br}$ s, $\left.1 \mathrm{H}, \beta-\mathrm{H}^{\mathrm{L}-\mathrm{Hep}}\right), 3.97$ (br s, $\left.1 \mathrm{H}, \alpha-\mathrm{H}^{\mathrm{D}-\mathrm{Hep}}\right), 4.00\left(\mathrm{dd},{ }^{3} J_{2,3}=3.1\right.$, $\left.{ }^{3} J_{3,4}=9.0 \mathrm{~Hz}, 1 \mathrm{H}, \mathrm{H} 3\right), 4.07-4.14\left(\mathrm{~m}, 4 \mathrm{H}, \delta-\mathrm{H}_{\mathrm{b}}{ }^{\mathrm{D}-\mathrm{Hep}}, \delta-\mathrm{H}_{\mathrm{b}}{ }^{\mathrm{L}-\mathrm{Hep}}, \mathrm{H} 2\right.$, $\mathrm{H} 4), 4.25$ (br t, $\left.{ }^{3} J=6.6 \mathrm{~Hz}, 1 \mathrm{H}, \beta-\mathrm{H}^{\mathrm{D}-H e p}\right), 4.28,4.34$ ( $2 \mathrm{~d}$, each 1 $\left.\mathrm{H}, \mathrm{OCH}_{2}{ }^{\mathrm{Bn}}\right), 4.34-4.41\left(\mathrm{~m}, 1 \mathrm{H}, \alpha-\mathrm{H}^{\mathrm{mePhe}}\right), 4.26-4.49(\mathrm{~m}, 7 \mathrm{H}, 3.5$ $\left.\mathrm{OCH}_{2}{ }^{\mathrm{B}}\right), 4.49-4.59\left(\mathrm{~m}, 2 \mathrm{H}, \alpha-\mathrm{H}^{\mathrm{L}-\mathrm{Hep}}, \alpha-\mathrm{H}^{\mathrm{Ser}}\right), 4.51,4.54,4.69,4.70$ ( $3 \mathrm{~d}$ and $\left.1 \mathrm{~s}, 5 \mathrm{H}, 2.5 \mathrm{OCH}_{2}{ }^{\mathrm{Bn}}\right), 4.65-4.78\left(\mathrm{~m}, 3 \mathrm{H}, \alpha-\mathrm{H}^{\mathrm{Tyr}}, \mathrm{OH}^{\mathrm{D}-\mathrm{Hep}}\right.$, $\left.\mathrm{OH}^{\mathrm{L}-\mathrm{Hep}}\right), 5.20\left(\mathrm{t},{ }^{3} J_{3^{\prime} 4^{\prime}}={ }^{3} J_{4^{\prime}, 5^{\prime}}=9.6 \mathrm{~Hz}, 1 \mathrm{H}, \mathrm{H} 4^{\prime}\right), 5.29\left(\mathrm{~d},{ }^{3} J_{1^{\prime} 2^{\prime}}=\right.$ $\left.2.0 \mathrm{~Hz}, 1 \mathrm{H}, \mathrm{H} 1^{\prime}\right), 5.56\left(\mathrm{~d},{ }^{3} J_{1,2}=2.1 \mathrm{~Hz}, 1 \mathrm{H}, \mathrm{H1}\right), 7.00-7.40(\mathrm{~m}$, $45 \mathrm{H}, \mathrm{H}_{\text {arom }}, \mathrm{NH}^{\mathrm{L}-\mathrm{Hep}}$ ), 7.76 (br s, $1 \mathrm{H}, \mathrm{NH}^{\text {mePhe }}$ ), 7.83 (br s, $1 \mathrm{H}, \mathrm{NH}-$ Gly), 8.26 (br s, $\left.1 \mathrm{H}, \mathrm{NH}^{\mathrm{Ser}}\right), 8.42\left(\mathrm{br} \mathrm{d},{ }^{3} J=8.4 \mathrm{~Hz}, 1 \mathrm{H}, \mathrm{NH}^{\mathrm{Tyr}}\right), 8.58$ (br s, $1 \mathrm{H}, \mathrm{NH}^{\mathrm{D}-\mathrm{Hep}}$ ).

${ }^{13} \mathrm{C}$ NMR: $\left(126 \mathrm{MHz}, 350 \mathrm{~K}\right.$, DMSO- $\left.d_{6}\right): \delta=18.0\left(\mathrm{CH}_{3}{ }^{\mathrm{mePhe}}\right), 21.3$ $\left(2 \mathrm{CH}_{3}{ }^{i \mathrm{Val}}\right), 23.5,23.7\left(2 \mathrm{CH}_{3}{ }^{i-\mathrm{Pr}}\right), 23.9\left(\mathrm{CH}^{i \mathrm{Val}}\right), 25.3,25.6(2$ $\left.\mathrm{CH}_{3}{ }^{i-\mathrm{Pr}}\right), 27.4\left(\mathrm{CH}_{3}^{\mathrm{Boc}}\right), 27.5\left(\mathrm{CH}_{3}{ }^{\mathrm{Boc}}\right), 34.6\left(\mathrm{C}-\beta_{\mathrm{Tyr}}\right), 39.7\left(\mathrm{C}-\beta^{\mathrm{mePhe}}\right)$, $40.8\left(\mathrm{CH}_{2}{ }^{\mathrm{Gly}}\right), 42.0\left(\mathrm{CH}_{2}{ }^{i \mathrm{Val}}\right), 51.2\left(\mathrm{C}-\alpha^{\mathrm{Ser}}\right), 53.1\left(\mathrm{C}-\alpha^{\mathrm{Tyr}}\right), 54.1(\mathrm{C}-$ $\left.\alpha^{\mathrm{L}-\mathrm{Hep}}\right), 56.7\left(\mathrm{C}-\alpha^{\text {mePhe }}\right), 57.4\left(\mathrm{C}-\alpha^{\mathrm{D}-\mathrm{Hep}}\right), 57.8\left(\mathrm{C}-\gamma^{\mathrm{D}-\mathrm{Hep}}, \mathrm{C}-\gamma^{\mathrm{L}-\mathrm{Hep}}\right)$, $62.0\left(\mathrm{C}-\delta^{\mathrm{D}-\mathrm{Hep}}\right), 62.5\left(\mathrm{C}-\delta^{\mathrm{L}-\mathrm{Hep}}\right), 67.2\left(\mathrm{C}^{\prime}\right), 68.0\left(\mathrm{C}-\beta^{\mathrm{L}-\mathrm{Hep}}\right), 68.5(\mathrm{C}-$ $\left.\beta^{\text {Ser }}\right), 68.6\left(\mathrm{C} 6, \mathrm{C6}^{\prime}\right), 69.8,70.1\left(\mathrm{CH}_{2} \mathrm{Ph}\right), 70.3\left(\mathrm{C}-\beta^{\mathrm{D}-\mathrm{Hep}}\right), 70.4(\mathrm{C} 5)$, 71.2 (C5'), 71.3, 71.4, 71.6, 71.8, $71.9\left(\mathrm{CH}_{2} \mathrm{Ph}\right), 72.8(\mathrm{C} 4), 73.1$ $(\mathrm{C} 2), 74.3\left(\mathrm{C} 2{ }^{\prime}\right), 75.8\left(\mathrm{C}^{\prime}\right), 78.5(\mathrm{C} 3), 78.2,79.2\left(\mathrm{C}_{\mathrm{q}}{ }^{\mathrm{Boc}}\right), 92.4,92.7$ $\left(\mathrm{C}_{\mathrm{q}}{ }^{i-\mathrm{Pr}}\right), 95.7\left(\mathrm{C} 1^{\prime}\right), 98.3(\mathrm{C} 1), 116.1,125.5-142.7\left(\mathrm{C}_{\text {arom }}\right), 154.3(p-$ $\left.\mathrm{C}_{\text {arom }}{ }^{\text {Tyr }}\right), 170.5\left(\mathrm{C}=\mathrm{O}^{i \mathrm{Val}}\right)$.

HRMS (ESI): $m / z[\mathrm{M}+\mathrm{H}]^{+}$calcd for $\mathrm{C}_{116} \mathrm{H}_{143} \mathrm{~N}_{8} \mathrm{O}_{27}: 2081.0096$; found: 2081.0107 .

Methyl $N$-(2,3,4,6-Tetra- $O$-benzyl- $\alpha$-D-mannopyranosyloxycarbonyl)-L-phenylalaninate (19)

Sulfoxide 1 (259 mg, 0.4 mmol, 1.8 equiv) and DTBP $(0.15 \mathrm{~mL}$, $0.69 \mathrm{mmol}, 3.1$ equiv) were coevaporated with toluene $(2 \times 5 \mathrm{~mL})$. The residue was dissolved in $\mathrm{CH}_{2} \mathrm{Cl}_{2}(2 \mathrm{~mL})$, molecular sieves $(4 \AA)$ were added, and the resulting mixture was stirred at r.t. for $30 \mathrm{~min}$ under argon. After cooling the mixture to $-70{ }^{\circ} \mathrm{C}, \mathrm{Tf}_{2} \mathrm{O}(52 \mu \mathrm{L}$, $0.31 \mathrm{mmol}, 1.4$ equiv) was added dropwise, followed by a soln of Boc-L-Phe-OMe (56 mg, $0.22 \mathrm{mmol}, 1$ equiv) in $\mathrm{CH}_{2} \mathrm{Cl}_{2}(1 \mathrm{~mL})$. After stirring for $18 \mathrm{~h}$ at $-25^{\circ} \mathrm{C}$, the reaction was quenched by the addition of $\mathrm{MeOH}(0.1 \mathrm{~mL})$, diluted with $\mathrm{CH}_{2} \mathrm{Cl}_{2}(30 \mathrm{~mL})$, and poured into a mixture of sat. aq $\mathrm{NaHCO}_{3}$-brine $(1: 1,30 \mathrm{~mL})$. The aqueous phase was extracted with $\mathrm{CH}_{2} \mathrm{Cl}_{2}(3 \times 20 \mathrm{~mL})$ and the combined organic phases were dried $\left(\mathrm{MgSO}_{4}\right)$ and evaporated. Purification of the residue by flash chromatography (PE-EtOAc, 4:1) afforded glycocarbamate $19(124 \mathrm{mg}, 75 \%)$ as a colorless solid. Crystallization of an analytical sample $\left(\mathrm{PE}-\mathrm{THF}-\mathrm{Et}_{2} \mathrm{O}\right)$ gave crystals suitable for X-ray analysis. ${ }^{27} R_{f}=0.20$ (PE-EtOAc, 4:1).

${ }^{1} \mathrm{H}$ NMR (400 MHz, acetone- $\left.d_{6}\right): \delta=3.00\left(\mathrm{dd},{ }^{2} J=13.8,{ }^{3} J_{\alpha, \beta a}=9.1\right.$ $\left.\mathrm{Hz}, 1 \mathrm{H}, \beta-\mathrm{H}_{\mathrm{a}}{ }^{\mathrm{Phe}}\right), 3.17\left(\mathrm{dd}, J=13.8,{ }^{3} J_{\alpha, \beta \mathrm{b}}=5.3 \mathrm{~Hz}, 1 \mathrm{H}, \beta-\mathrm{H}_{\mathrm{b}}{ }^{\text {Phe }}\right)$, $3.65\left(\mathrm{~s}, 3 \mathrm{H}, \mathrm{OCH}_{3}\right), 3.66-3.73\left(\mathrm{~m}, 1 \mathrm{H}, \mathrm{Hb}_{\mathrm{a}}\right), 3.75-3.83(\mathrm{~m}, 2 \mathrm{H}$, $\left.\mathrm{H}_{\mathrm{b}}, \mathrm{H} 5\right), 3.86-3.94$ (m, $\left.2 \mathrm{H}, \mathrm{H} 2, \mathrm{H} 3\right), 4.03$ (t, $\left.{ }^{3} \mathrm{~J}=9.3 \mathrm{~Hz}, 1 \mathrm{H}, \mathrm{H} 4\right)$, $4.43-4.55\left(\mathrm{~m}, 1 \mathrm{H}, \alpha-\mathrm{H}^{\mathrm{Phe}}\right), 4.51-4.90\left(\mathrm{~m}, 8 \mathrm{H}, 4 \mathrm{OCH}_{2}^{\mathrm{Bn}}\right), 6.04(\mathrm{~d}$, $\left.{ }^{3} J_{1,2}=1.5 \mathrm{~Hz}, 1 \mathrm{H}, \mathrm{H} 1\right), 6.94\left(\mathrm{~d},{ }^{3} J_{\mathrm{NH}, \alpha}=8.8 \mathrm{~Hz}, 1 \mathrm{H}, \mathrm{NH}\right), 7.16-$ $7.46\left(\mathrm{~m}, 25 \mathrm{H}, \mathrm{H}_{\text {arom }}\right)$.

${ }^{13} \mathrm{C}$ NMR $\left(100 \mathrm{MHz}\right.$, acetone- $\left.d_{6}\right): \delta=38.2\left(\mathrm{C}-\beta^{\mathrm{Phe}}\right), 52.4\left(\mathrm{OCH}_{3}\right)$, $56.4\left(\mathrm{C}-\alpha^{\text {Phe }}\right), 70.1(\mathrm{C} 6), 72.4,73.3,73.8\left(3 \times \mathrm{CH}_{2} \mathrm{Ph}\right), 74.8(\mathrm{C} 5)$, 75.3 (C2, C4), $75.5\left(\mathrm{CH}_{2} \mathrm{Ph}\right), 80.7$ (C3), 93.1 (C1), 127.6, 128.1, 128.2, 128.3, 128.5, 128.6, 128.6, 128.7, 129.0, 129.0, 129.1, 129.1, $129.2,130.1\left(\mathrm{CH}_{\text {arom }}\right), 138.1,139.7,139.8,139.8,139.9\left(\mathrm{C}_{\text {arom }}\right)$, $154.8\left(\mathrm{C}=\mathrm{O}_{\text {carbamate }}\right), 172.6(\mathrm{COOMe})$.

HRMS (ESI): $m / z[\mathrm{M}+\mathrm{Na}]^{+}$calcd for $\mathrm{C}_{45} \mathrm{H}_{47} \mathrm{NNaO}_{9}$ : 745.3251; found: 745.3257 .

\section{$N$-(2,3,4,6-Tetra- $O$-benzyl-a-D-mannopyranosyloxycarbonyl)-} L-phenylalanine (20)

To a soln of ester $19(24 \mathrm{mg}, 32 \mu \mathrm{mol})$ in 1,4-dioxane $(0.4 \mathrm{~mL})$ was added at $8{ }^{\circ} \mathrm{C}$ aq $1 \mathrm{M} \mathrm{LiOH}$ soln $(64 \mu \mathrm{L}, 64 \mu \mathrm{mol}, 2$ equiv). The mixture was stirred for $3 \mathrm{~h}$ at this temperature and then it was diluted with EtOAc $(20 \mathrm{~mL})$, washed with sat. aq $\mathrm{NH}_{4} \mathrm{Cl}-\mathrm{H}_{2} \mathrm{O}(1: 1)$, and dried $\left(\mathrm{MgSO}_{4}\right)$. Evaporation of the solvent gave acid $20(21 \mathrm{mg}$, $89 \%)$ as a colorless solid; $R_{f}=0.50\left(\mathrm{CH}_{2} \mathrm{Cl}_{2}-\mathrm{MeOH}, 9: 1\right)$. 
${ }^{1} \mathrm{H}$ NMR (400 MHz, acetone- $\left.d_{6}\right): \delta=2.96\left(\mathrm{dd},{ }^{2} J=14.0,{ }^{3} J_{\alpha, \beta a}=8.4\right.$ $\left.\mathrm{Hz}, 1 \mathrm{H}, \beta-\mathrm{H}_{\mathrm{a}}{ }^{\text {Phe }}\right), 3.19\left(\mathrm{dd},{ }^{2} J=14.0,{ }^{3} J_{\alpha, \beta \mathrm{b}}=4.9 \mathrm{~Hz}, 1 \mathrm{H}, \beta-\mathrm{H}_{\mathrm{b}}{ }^{\text {Phe }}\right)$, $3.64\left(\mathrm{dd},{ }^{2} J=11.0,{ }^{3} J_{5,6 \mathrm{a}}=1.7 \mathrm{~Hz}, 1 \mathrm{H}, \mathrm{H6} \mathrm{a}_{\mathrm{a}}\right), 3.70-3.76(\mathrm{~m}, 2 \mathrm{H}, \mathrm{H} 5$, $\left.\mathrm{H}_{\mathrm{b}}\right), 3.74\left(\mathrm{dd},{ }^{3} J_{1,2}=2.1,{ }^{3} J_{2,3}=3.2 \mathrm{~Hz}, 1 \mathrm{H}, \mathrm{H} 2\right), 3.80\left(\mathrm{dd},{ }^{3} J_{2,3}=\right.$ $\left.3.1,{ }^{3} J_{3,4}=9.5 \mathrm{~Hz}, 1 \mathrm{H}, \mathrm{H} 3\right), 4.02\left(\mathrm{t},{ }^{3} J_{3,4}={ }^{3} J_{4,5}=9.7 \mathrm{~Hz}, 1 \mathrm{H}, \mathrm{H} 4\right)$, $4.44\left(\mathrm{dd},{ }^{3} J_{\alpha, \beta \mathrm{a}}=9.0,{ }^{3} J_{\alpha, \beta \mathrm{b}}=5.4 \mathrm{~Hz}, 1 \mathrm{H}, \alpha-\mathrm{H}^{\text {Phe }}\right), 4.44-4.84(\mathrm{~m}, 8$ $\left.\mathrm{H}, 4 \mathrm{CH}_{2}{ }^{\mathrm{Bn}}\right), 6.03\left(\mathrm{~d},{ }^{3} J_{1,2}=2.0 \mathrm{~Hz}, 1 \mathrm{H}, \mathrm{H} 1\right), 7.10-7.39(\mathrm{~m}, 25 \mathrm{H}$ $\mathrm{H}_{\text {arom }}$ ).

${ }^{13} \mathrm{C}$ NMR $\left(100 \mathrm{MHz}\right.$, acetone- $\left.d_{6}\right): \delta=38.2\left(\mathrm{C}-\beta^{\text {Phe }}\right), 55.9\left(\mathrm{C}-\alpha^{\text {Phe }}\right)$, 67.7 (C6), 69.3, 72.7, $73.1\left(3 \mathrm{CH}_{2}{ }^{\mathrm{Bn}}\right), 74.1$ (C5), 74.5 (C2), 74.9 (C4), $75.8\left(\mathrm{CH}_{2}^{\mathrm{Bn}}\right), 80.0(\mathrm{C} 3), 92.9(\mathrm{C} 1), 127.4,128.2,128.3,128.4$, $128.7,128.7,128.9,129.0\left(\mathrm{CH}_{\text {arom }}\right), 129.9\left(o-\mathrm{CH}_{\text {arom }}{ }^{\text {Phe }}\right), 137.6$ $138.5,138.8\left(\mathrm{C}_{\text {arom }}\right), 155.1\left(\mathrm{C}=\mathrm{O}_{\text {carbamate }}\right), 174.4(\mathrm{COOH})$.

HRMS (ESI): $m / z[\mathrm{M}+\mathrm{Na}]^{+}$calcd for $\mathrm{C}_{44} \mathrm{H}_{45} \mathrm{NNaO}_{9}: 754.2987$; found: 754.2975 .

\section{Methyl $\boldsymbol{N}$-( $\alpha$-D-Mannopyranosyloxycarbonyl)-L-phenylalani- nate (21)}

Glycocarbamate $19(24 \mathrm{mg}, 32 \mu \mathrm{mol})$ was dissolved in $\mathrm{MeOH}$ $(0.5 \mathrm{~mL})$, and $10 \% \mathrm{Pd} / \mathrm{C}$ was added $(5 \mathrm{mg})$. The mixture was stirred at r.t. under an atmosphere of $\mathrm{H}_{2}$ (1 bar) for $12 \mathrm{~h}$, diluted with $\mathrm{CH}_{2} \mathrm{Cl}_{2}(2 \mathrm{~mL})$, and purified directly by flash chromatography $\left(\mathrm{CH}_{2} \mathrm{Cl}_{2}-\mathrm{MeOH}, 6: 1\right)$, which afforded the tetraol 21 (8 mg, 64\%) as a colorless solid; $R_{f}=0.25\left(\mathrm{CH}_{2} \mathrm{Cl}_{2}-\mathrm{MeOH}, 9: 1\right)$.

${ }^{1} \mathrm{H} \mathrm{NMR}\left(400 \mathrm{MHz}, \mathrm{CD}_{3} \mathrm{OD}\right): \delta=2.95\left(\mathrm{dd}, J=13.8,{ }^{3} J_{\beta_{\mathrm{a}}}=9.3 \mathrm{~Hz}\right.$, $\left.1 \mathrm{H}, \beta-\mathrm{H}_{\mathrm{a}}{ }^{\text {Phe }}\right), 3.16\left(\mathrm{dd}, J=13.8,{ }^{3} J_{\alpha, \beta \mathrm{b}}=5.2 \mathrm{~Hz}, 1 \mathrm{H}, \beta-\mathrm{H}_{\mathrm{b}}{ }^{\text {Phe }}\right), 3.59$ $3.64(\mathrm{~m}, 1 \mathrm{H}, \mathrm{H} 5), 3.66-3.74\left(\mathrm{~m}, 3 \mathrm{H}, \mathrm{H} 4, \mathrm{H} 3, \mathrm{H6}_{\mathrm{a}}\right), 3.70(\mathrm{~s}, 3 \mathrm{H}$, $\left.\mathrm{OCH}_{3}\right), 3.74\left(\mathrm{dd},{ }^{3} J_{1,2}=1.7,{ }^{3} J_{2,3}=3.2 \mathrm{~Hz}, 1 \mathrm{H}, \mathrm{H} 2\right), 3.79\left(\mathrm{dd},{ }^{2} \mathrm{~J}=\right.$ $\left.12.1,{ }^{3} J_{5,6 \mathrm{~b}}=2.2 \mathrm{~Hz}, 1 \mathrm{H}, \mathrm{H6}_{\mathrm{b}}\right), 4.41\left(\mathrm{dd},{ }^{3} J_{\alpha, \beta \mathrm{a}}=9.3,{ }^{3} J_{\alpha, \beta \mathrm{b}}=5.3 \mathrm{~Hz}\right.$, $\left.1 \mathrm{H}, \alpha-\mathrm{H}^{\mathrm{Phe}}\right), 5.80\left(\mathrm{~d},{ }^{3} J_{1,2}=1.9 \mathrm{~Hz}, 1 \mathrm{H}, \mathrm{H} 1\right), 7.18-7.25(\mathrm{~m}, 5 \mathrm{H}$, $\left.\mathrm{CH}_{\text {arom }}\right)$.

${ }^{13} \mathrm{C}$ NMR $\left(100 \mathrm{MHz}, \mathrm{CD}_{3} \mathrm{OD}\right): \delta=38.5\left(\mathrm{C}-\beta^{\mathrm{Phe}}\right), 52.7\left(\mathrm{OCH}_{3}\right), 57.0$ $\left(\mathrm{C}-\alpha^{\mathrm{Phe}}\right), 62.7(\mathrm{C} 6), 68.0(\mathrm{C} 4), 71.2(\mathrm{C} 2), 72.2(\mathrm{C} 3), 76.6(\mathrm{C} 5), 96.1$ (C1), 127.9, 129.5, 130.3, $138.3\left(\mathrm{C}_{\text {arom }}\right), 156.4\left(\mathrm{C}=\mathrm{O}_{\text {carbamate }}\right), 173.6$ (COOMe).

HRMS (ESI): $m / z[\mathrm{M}+\mathrm{Na}]^{+}$calcd for $\mathrm{C}_{17} \mathrm{H}_{23} \mathrm{NNaO}_{9}: 408.1265$; found: 408.1259 .

\section{Methyl $N$-(2,3,4,6-Tetra- $O$-benzyl-a-D-mannopyranosyloxycar- bonyl)-L-prolinate (22)}

Boc-L-Pro-OMe $(27 \mathrm{mg}, 118 \mu \mathrm{mol}, 1$ equiv) and DTBP $(98 \mu \mathrm{L}$, $425 \mu \mathrm{mol}, 3.6$ equiv) were coevaporated with toluene $(2 \times 5 \mathrm{~mL})$. The residue was dissolved in $\mathrm{CH}_{2} \mathrm{Cl}_{2}(2 \mathrm{~mL})$, molecular sieves $(4 \AA)$ were added, and the resulting mixture was stirred at r.t. for $30 \mathrm{~min}$ under argon. After cooling the mixture to $-70{ }^{\circ} \mathrm{C}, \mathrm{Tf}_{2} \mathrm{O}(35 \mu \mathrm{L}$, $212 \mu \mathrm{mol}, 1.8$ equiv) was added dropwise, followed by a soln of sulfoxide 1 (138 mg, $212 \mu \mathrm{mol}, 1.8$ equiv) in $\mathrm{CH}_{2} \mathrm{Cl}_{2}(1 \mathrm{~mL})$, and the mixture was slowly warmed to r.t. over $5 \mathrm{~h}$. The reaction was quenched by the addition of $\mathrm{MeOH}(0.1 \mathrm{~mL})$, diluted with $\mathrm{CH}_{2} \mathrm{Cl}_{2}$ $(30 \mathrm{~mL})$, and poured into a mixture of sat. aq $\mathrm{NaHCO}_{3}$-brine $(1: 1$, $30 \mathrm{~mL})$. The aqueous phase was extracted with $\mathrm{CH}_{2} \mathrm{Cl}_{2}(3 \times 20 \mathrm{~mL})$ and the combined organic phases were dried $\left(\mathrm{MgSO}_{4}\right)$ and evaporated. Purification of the residue by flash chromatography (PEEtOAc, 4:1, 3:1) afforded glycocarbamate $22(65 \mathrm{mg}, 79 \%)$ as a colorless oil; $R_{f}=0.40$ (PE-EtOAc, 2:1).

${ }^{1} \mathrm{H}$ NMR $\left(400 \mathrm{MHz}, \mathrm{DMSO}-d_{6}\right.$, mixture of cis- and trans-isomers, ratio $3: 2): \delta=1.77-1.96\left(\mathrm{~m}, 3 \mathrm{H}\right.$, cis- + trans $\left.-\beta^{\text {Pro }}-\mathrm{H}_{\mathrm{a}}, 2 \gamma^{\text {Pro }}-\mathrm{H}\right)$, $2.13-2.30\left(\mathrm{~m}, 1 \mathrm{H}\right.$, cis- $^{-}$trans $\left.-\beta^{\text {Pro }}-\mathrm{H}_{\mathrm{b}}\right), 3.28-3.35\left(\mathrm{~m}, 1.2 \mathrm{H}\right.$, cis- $^{-}$ $\left.\delta^{\text {Pro }}-\mathrm{CH}_{2}\right), 3.41\left(\mathrm{t},{ }^{3} J_{\gamma, \delta}=7.0 \mathrm{~Hz}, 0.8 \mathrm{H}\right.$, trans $\left.-\delta^{\text {Pro }}-\mathrm{CH}_{2}\right), 3.58(\mathrm{~s}, 1.2$ $\mathrm{H}$, trans $\left.-\mathrm{OCH}_{3}\right), 3.60-3.64\left(\mathrm{~m}, 1 \mathrm{H}\right.$, cis- + trans $\left.-\mathrm{H}_{\mathrm{a}}\right), 3.61(\mathrm{~s}, 1.8$ $\mathrm{H}$, cis- $\left.-\mathrm{OCH}_{3}\right), 3.65-3.74(\mathrm{~m}, 2.4 \mathrm{H}$, trans $-\mathrm{H} 3$, cis- + trans $-\mathrm{H} 4$, cis+ trans $\left.-\mathrm{H} 6_{\mathrm{b}}\right), 3.79-3.84(\mathrm{~m}, 1 \mathrm{H}$, trans $-\mathrm{H} 2$, cis-H3), 3.84-3.93 (m, $1.6 \mathrm{H}$, cis-H2, cis- + trans-H5), $4.24\left(\mathrm{dd},{ }^{3} J_{\alpha, \beta}=3.9,{ }^{3} J_{\alpha, \beta}=9.0 \mathrm{~Hz}\right.$, $0.6 \mathrm{H}$, cis- $\left.\alpha^{\mathrm{Pro}}-\mathrm{CH}\right), 4.35\left(\mathrm{dd},{ }^{3} J_{\alpha, \beta}=4.1,{ }^{3} J_{\alpha, \beta}=8.5 \mathrm{~Hz}, 0.4 \mathrm{H}\right.$, trans $\left.\alpha^{\text {Pro }}-\mathrm{CH}\right), 4.43-4.81\left(\mathrm{~m}, 8 \mathrm{H}, 4 \mathrm{CH}_{2} \mathrm{Ph}\right), 5.95\left(\mathrm{~d},{ }^{3} J_{1,2}=1.8 \mathrm{~Hz}, 0.6\right.$ $\mathrm{H}$, cis- $\mathrm{H} 1), 5.97\left(\mathrm{~d},{ }^{3} J_{1,2}=1.8 \mathrm{~Hz}, 0.4 \mathrm{H}\right.$, trans-H1), 7.16-7.23, 7.24-7.39 (2 m, $2 \mathrm{H}$ and $18 \mathrm{H}$, cis- + trans $\left.-\beta_{\mathrm{H}} \mathrm{arom}\right)$.
${ }^{13} \mathrm{C}$ NMR $\left(100 \mathrm{MHz}, \mathrm{DMSO}-d_{6}\right): \delta=23.1$ (trans $\left.-\mathrm{C}-\gamma^{\mathrm{Pro}}\right), 23.7$ (cis-

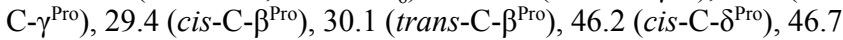
(trans-C- $\left.\delta^{\text {Pro }}\right), 51.9\left(\right.$ cis- $\left.\mathrm{OCH}_{3}\right), 52.0\left(\right.$ trans- $\left.\mathrm{OCH}_{3}\right), 58.5$ (trans-C$\left.\alpha^{\text {Pro }}\right), 58.7$ (cis-C- $\left.\alpha^{\text {Pro }}\right), 68.7$ (C6), $70.7\left(\mathrm{CH}_{2} \mathrm{Ph}\right), 71.0$ (C5), 71.9, 71.9, 72.3, 72.3, $73.3(\mathrm{C} 4), 73.4(\mathrm{C} 2), 73.6\left(\mathrm{CH}_{2} \mathrm{Ph}\right), 73.7,73.8$, 73.9, 74.2, 78.2 (cis-C3), 79.6 (trans-C3), 91.9 (C1), 127.3, 127.4, 127.4, 127.4, 127.5, 127.5, 127.5, 127.6, 127.6, 127.7, 127.7, 127.8, $128.1,128.2,128.2,128.2,139.8,139.8,139.9\left(\mathrm{C}_{\text {arom }}\right), 151.2$ (trans $\left.-\mathrm{C}=\mathrm{O}^{\text {carbamate }}\right), 151.8\left(\right.$ cis $\left.-\mathrm{C}=\mathrm{O}^{\text {carbamate }}\right), 172.3$ (cis-COOMe), 172.8 (trans-COOMe).

HRMS (ESI): $m / z[\mathrm{M}+\mathrm{Na}]^{+}$calcd for $\mathrm{C}_{41} \mathrm{H}_{45} \mathrm{NNaO}_{9}$ : 718.2992; found: 718.2975 .

$N^{\alpha}$-Fmoc-L-Lys- $N^{z}$-(2,3,4,6-tetra- $O$-benzyl- $\alpha$-D-mannopyranosyloxycarbonyl)-L-Phe-OMe (23)

Perbenzylated sulfoxide 1 (129 mg, $0.2 \mathrm{mmol}, 1.5$ equiv) and DTBP $(91 \mu \mathrm{L}, 0.41 \mathrm{mmol}, 3.1$ equiv) were coevaporated with toluene $(2 \times 5 \mathrm{~mL})$. The residue was dissolved in $\mathrm{CH}_{2} \mathrm{Cl}_{2}(4 \mathrm{~mL})$, and molecular sieves $(4 \AA)$ were added. The resulting mixture was stirred for $30 \mathrm{~min}$ under an argon atmosphere. The mixture was cooled $-70{ }^{\circ} \mathrm{C}$ and $\mathrm{Tf}_{2} \mathrm{O}(30 \mu \mathrm{L}, 0.2 \mathrm{mmol}, 1.5$ equiv) was added dropwise followed by a soln of Fmoc-L-Lys-( $N^{\varepsilon}$-Boc)-L-Phe-OMe $(83 \mathrm{mg}, 131 \mu \mathrm{mol})$ in $\mathrm{CH}_{2} \mathrm{Cl}_{2}(5 \mathrm{~mL})$. The mixture was stirred at $-25{ }^{\circ} \mathrm{C}$ for $18 \mathrm{~h}$, and the reaction was stopped by the addition of $\mathrm{MeOH}(0.3 \mathrm{~mL})$, diluted with $\mathrm{CH}_{2} \mathrm{Cl}_{2}(30 \mathrm{~mL})$ and poured into sat. aq $\mathrm{NaHCO}_{3}$-brine $-\mathrm{H}_{2} \mathrm{O}(1: 1: 2,30 \mathrm{~mL})$. The aqueous phase was extracted with $\mathrm{CH}_{2} \mathrm{Cl}_{2}(3 \times 20 \mathrm{~mL})$, and the combined organic phases were dried $\left(\mathrm{MgSO}_{4}\right)$ and evaporated. The residue was purified by flash chromatography $\left(\mathrm{CH}_{2} \mathrm{Cl}_{2}-\mathrm{MeOH}, 100: 1\right.$, then 80:1), which afforded mannosyl carbamate $\mathbf{2 3}$ (43 $\mathrm{mg}, 39 \mu \mathrm{mol}, 44 \%$ ) as a colorless solid; $R_{f}=0.30\left(\mathrm{CH}_{2} \mathrm{Cl}_{2}-\mathrm{MeOH}, 40: 1\right)$.

${ }^{1} \mathrm{H}$ NMR $\left(500 \mathrm{MHz}\right.$, acetone- $\left.d_{6}\right): \delta=1.32-1.46\left(\mathrm{~m}, 2 \mathrm{H}, 2 \gamma-\mathrm{H}^{\mathrm{Lys}}\right)$, $1.47-1.57\left(\mathrm{~m}, 2 \mathrm{H}, 2 \delta-\mathrm{H}^{\mathrm{Lys}}\right), 1.59-1.70\left(\mathrm{~m}, 1 \mathrm{H}, \beta-\mathrm{H}_{\mathrm{a}}^{\text {Lys }}\right), 1.74-1.85$ $\left(\mathrm{m}, 1 \mathrm{H}, \beta-\mathrm{H}_{\mathrm{b}}^{\text {Lys }}\right), 3.02\left(\mathrm{dd}, J=13.8,{ }^{3} J_{\alpha, \beta \mathrm{a}}=7.8 \mathrm{~Hz}, 1 \mathrm{H}, \beta-\mathrm{H}_{\mathrm{a}}^{\text {Phe }}\right)$, $3.09-3.18\left(\mathrm{~m}, 3 \mathrm{H}, \beta-\mathrm{H}_{\mathrm{b}}{ }^{\mathrm{Ph}}, 2 \varepsilon-\mathrm{H}^{\mathrm{Lys}}\right), 3.64\left(\mathrm{~s}, 3 \mathrm{H}, \mathrm{OCH}_{3}\right), 3.69(\mathrm{~d}$, $\left.{ }^{2} J=10.7 \mathrm{~Hz}, 1 \mathrm{H}, \mathrm{H6}_{\mathrm{a}}\right), 3.77\left(\mathrm{dd},{ }^{2} J=11.2,{ }^{3} J_{5,6 \mathrm{~b}}=4.7 \mathrm{~Hz}, 1 \mathrm{H}, \mathrm{H6}_{\mathrm{b}}\right)$, $3.79-3.84(\mathrm{~m}, 1 \mathrm{H}, \mathrm{H} 5), 3.91\left(\mathrm{dd},{ }^{3} J_{2,3}=3.0,{ }^{3} J_{3,4}=9.5 \mathrm{~Hz}, 1 \mathrm{H}, \mathrm{H} 3\right)$, $3.98\left(\mathrm{dd},{ }^{3} J_{1,2}=1.7,{ }^{3} J_{2,3}=3.0 \mathrm{~Hz}, 1 \mathrm{H}, \mathrm{H} 2\right), 4.04\left(\mathrm{t},{ }^{3} J_{3,4}={ }^{3} J_{4,5}=\right.$ $9.3 \mathrm{~Hz}, 1 \mathrm{H}, \mathrm{H} 4), 4.15-4.21\left(\mathrm{~m}, 1 \mathrm{H}, \alpha-\mathrm{H}^{\mathrm{Lys}}\right), 4.22$ (br t, ${ }^{3} J=7.3 \mathrm{~Hz}$, $\left.1 \mathrm{H}, \mathrm{CH}^{\mathrm{Fmoc}}\right), 4.26-4.39\left(\mathrm{~m}, 2 \mathrm{H}, \mathrm{CH}_{2}{ }^{\mathrm{Fmoc}}\right), 4.51-4.68(\mathrm{~m}, 5 \mathrm{H}, 2$ $\left.\mathrm{CH}_{2}{ }^{\mathrm{Bn}}, \mathrm{CH}_{\mathrm{a}}{ }^{\mathrm{Bn}}\right), 4.69-4.75\left(\mathrm{~m}, 1 \mathrm{H}, \alpha-\mathrm{H}^{\mathrm{Phe}}\right), 4.76\left(\mathrm{br} \mathrm{s}, 2 \mathrm{H}, \mathrm{CH}_{2}{ }^{\mathrm{Bn}}\right)$, $4.89\left(\mathrm{~d},{ }^{2} J=11.0 \mathrm{~Hz}, 1 \mathrm{H}, \mathrm{CH}_{\mathrm{b}}{ }^{\mathrm{Bn}}\right), 6.14\left(\mathrm{~d},{ }^{3} \mathrm{~J}_{1,2}=1.7 \mathrm{~Hz}, 1 \mathrm{H}, \mathrm{H1}\right)$, 6.52-6.63 (m, $\left.2 \mathrm{H}, \alpha-\mathrm{NH}^{\mathrm{Lys}}, \varepsilon-\mathrm{NH}^{\mathrm{Lys}}\right), 7.12-7.46\left(\mathrm{~m}, 29 \mathrm{H}, \mathrm{H}_{\text {arom }}\right)$, $7.48\left(\mathrm{~d},{ }^{3} J_{\mathrm{NH}, \alpha}=7.8 \mathrm{~Hz}, 1 \mathrm{H}, \mathrm{NH}^{\text {Phe }}\right), 7.65-7.73\left(\mathrm{~m}, 2 \mathrm{H}, \mathrm{H}_{\text {arom }}\right.$ Foc $)$, $7.82-7.88\left(\mathrm{~m}, 2 \mathrm{H}, \mathrm{H}_{\text {arom }}{ }_{\mathrm{Fmoc}}\right)$.

${ }^{13} \mathrm{C}$ NMR $\left(125 \mathrm{MHz}\right.$, acetone- $\left.d_{6}\right): \delta=23.5\left(\gamma-\mathrm{C}^{\text {Lys }}\right), 30.3\left(\delta-\mathrm{C}^{\text {Lys }}\right)$, $32.6\left(\beta-C^{\text {Lys }}\right), 38.4\left(\beta-C^{\text {Phe }}\right), 41.4\left(\varepsilon-C^{\text {Lys }}\right), 48.1\left(\mathrm{C}^{\text {Fmoc }}\right), 52.4$ $\left(\mathrm{OCH}_{3}\right), 54.2\left(\alpha-\mathrm{C}^{\text {Phe }}\right), 56.2\left(\alpha-\mathrm{C}^{\mathrm{Lys}}\right), 67.3\left(\mathrm{CH}_{2}{ }^{\mathrm{Fmoc}}\right), 70.1(\mathrm{C} 6)$, 72.3, 73.3, 73.8, 75.4 (4 $\left.\mathrm{CH}_{2} \mathrm{Ph}\right), 74.7$ (C5), 75.6 (C4), 75.7 (C2), $80.8(\mathrm{C} 3), 92.6(\mathrm{C} 1), 120.8\left(\mathrm{CH}_{\text {arom }}{ }_{\mathrm{Fmoc}}\right), 126.2,127.6,128.1,128.2$, $128.3,128.5,128.6,128.6,128.6,129.0,129.0,129.1,129.1,129.2$ $\left(\mathrm{CH}_{\text {arom }}\right), 130.1\left(o-\mathrm{CH}_{\text {arom }}{ }^{\text {Phe }}\right), 136.8,138.1,139.7,139.8,139.8$, $139.9\left(\mathrm{C}_{\text {arom }}\right), 142.1\left(\mathrm{CH}_{\text {arom }}{ }^{\text {Fmoc }}\right), 145.0,145.1\left(\mathrm{C}_{\text {arom }}{ }^{\mathrm{Fmoc}}\right), 155.1$ $\left(\mathrm{C}=\mathrm{O}_{\text {carbamate }}{ }_{\text {Man }}\right), 157.0\left(\mathrm{C}=\mathrm{O}_{\text {carbamate }}{ }_{\mathrm{Fmoc}}\right), 172.5(\mathrm{COOMe})$.

HRMS (ESI): $m / z[\mathrm{M}+\mathrm{Na}]^{+}$calcd for $\mathrm{C}_{66} \mathrm{H}_{69} \mathrm{~N}_{3} \mathrm{NaO}_{12}: 1118.4779$; found: 1118.4799 .

\section{Acknowledgment}

This work was supported by the Deutsche Forschungsgemeinschaft DFG (Ob-332/1-1 and 1-2). P.S. thanks the Schering Foundation for a predoctoral fellowship.

Supporting Information for this article is available online at http://www.thieme-connect.com/ejournals/toc/synthesis. 


\section{References}

(1) Varki, A.; Lowe, J. B. Biological Roles of Glycans, In Essentials of Glycobiology, 2nd ed.; Varki, A.; Cummings, R. D.; Esko, J. D.; Freeze, H. H.; Stanley, P.; Bertozzi, C. R. Hart G. W.; Etzler, M. E., Eds.; Cold Spring Harbor Laboratory Press: Cold Spring Harbor NY, 2009.

(2) Zarschler, K.; Janesch, B.; Pabst, M.; Altmann, F.; Messner, P.; Schäffer, C. Glycobiology 2010, 20, 787; and literature cited therein.

(3) Halim, A.; Brinkmalm, G.; Rüetschi, U.; WestmanBrinkmalm, A.; Portelius, E.; Zetterberg, H.; Blennow, K.; Larson, G.; Nilsson, J. Proc. Natl. Acad. Soc. U.S.A. 2011, 108,11848 .

(4) Kahne, D.; Leimkuhler, C.; Lu, W.; Walsh, C. T. Chem. Rev. 2005, 105, 425 .

(5) Walker, S.; Chen, L.; Hu, Y.; Rew, Y.; Shin, D.; Boger, D. L. Chem. Rev. 2005, 105, 449 .

(6) (a) Plaza, A.; Gustchina, E.; Baker, H. L.; Kelly, M.; Bewley, C. A. J. Nat. Prod. 2007, 70, 1753. (b) Lu, Z.; Van Wagoner, R. M.; Harper, M. K.; Baker, H. L.; Hooper, J. N.; Bewley, C. A.; Ireland, C. M. J. Nat. Prod. 2011, 74, 185.

(7) (a) He, H.; Williamson, R. T.; Shen, B.; Graziani, E. I.; Yang, H. Y.; Sakya, S. M.; Petersen, P. J.; Carter, G. T. J. Am. Chem. Soc. 2002, 124, 9729. (b) Singh, M. P.; Petersen, P. J.; Weiss, W. J.; Janso, J. E.; Luckman, S. W.; Lenoy, E. B.; Bradford, P. A.; Testa, R. T.; Greenstein, M. Antimicrob. Agents Chemother. 2003, 47, 62.

(8) Koehn, F. E. J. Med. Chem. 2008, 51, 2613.

(9) Wang, T.-Z.; Wheless, K. L.; Sutherland, A. G.; Dushin, R. G. Heterocycles 2004, 62, 131.

(10) In contrast to glucose or galactose, mannosylations with donors that contain participating neighboring groups at $\mathrm{O} 2$ lead to $\alpha$-linked products because of the axial orientation of the 2-OH group in the mannose system.

(11) (a) Babu, R. S.; Guppi, S. R.; O'Doherty, G. A. Org. Lett. 2006, 8, 1605. (b) Guppi, S. R.; O’Doherty, G. A. J. Org. Chem. 2007, 72, 4966.

(12) Adinolfi, M.; Giacomini, D.; Iadonisi, A.; Quintavalla, A.; Valerio, S. Eur. J. Org. Chem. 2008, 2895.

(13) (a) Harreus, A.; Kunz, H. Liebigs Ann. Chem. 1986, 717. (b) Horvat, S.; Varga, L.; Horvat, J. Synthesis 1986, 209. (c) Salvador, L. A.; Elofsson, M.; Kihlberg, J. Tetrahedron 1995, 51, 5643. (d) Burger, K.; Kluge, M.; Fehn, S.; Koksch, B.; Henning, L.; Müller, G. Angew. Chem. Int. Ed. 1999, 38, 1414; Angew. Chem. 1999, 111, 1513 . (e) Fahmi, N. E.; Dedkova, L.; Wang, B.; Golovine, S.; Hecht, S. M. J. Am. Chem. Soc. 2007, 129, 3586. (f) Takahashi, S.; Hasumi, K.; Ohnishi, A.; Koshino, H.; Matsumoto, S. Bioorg. Med. Chem. 2007, 15, 97. (g) Liu, J.; Luo, C.; Smith, P. A.; Chin, J. K.; Page, M. G. P.; Paetzel, M.; Romersberg, F. E. J. Am. Chem. Soc. 2011, 133, 17869.

(14) (a) Jensen, K. J.; Meldal, M.; Bock, K. J. Chem. Soc., Perkin Trans. 1 1993, 2119. (b) Vargas-Berenguel, A.; Meldal, M.; Paulsen, H.; Jensen, K. J.; Bock, K. J. Chem. Soc., Perkin Trans. 1 1994, 3287.

(15) Review: Jensen, K. J. J. Chem. Soc., Perkin Trans. 12002 , 2019.

(16) (a) In the context of natural product synthesis, the vancomycin aglycon has been a major target for chemical glycosylation: Thompson, C.; Ge, M.; Kahne, D. J. Am. Chem. Soc. 1999, 121, 1237. (b) Nicolaou, K. C.; Mitchell, H. J.; Jain, N. F.; Bando, T.; Hughes, R.; Winssinger, N.; Natarajan, S.; Koumbis, A. Chem.-Eur. J. 1999, 5, 2648.

(17) Following a different strategy, the base-catalyzed conjugate addition of Boc-L-Tyr-OMe to 2-nitrogalactal afforded excellent yields of the corresponding $\alpha$-glycoside: Khodair,
A. I.; Winterfeld, G. A.; Schmidt, R. R. Eur. J. Org. Chem. 2003, 1847.

(18) Kahne, D.; Walker, S.; Cheng, Y.; Van Engen, D. J. Am. Chem. Soc. 1989, 111, 6881.

(19) Goddard-Borger, E. D.; Stick, R. V. Org. Lett. 2007, 9, 3797.

(20) The temporary protection of amino groups as azides or $N$ trifluoroacetyl amides can be problematic because of epimerization of the $\alpha$-carbon during peptide couplings and the subsequent deprotection.

(21) Crich, D.; Li, W.; Li, H. J. Am. Chem. Soc. 2004, 126, 15081.

(22) The olefin acts as a scavenger for the benzenesulfenic acid that is liberated during sulfoxide activation. In contrast to the original report, less scavenger ( 2 equiv instead of 10 equiv) was necessary to prevent thioglycoside activation: Gildersleeve, J.; Smith, A.; Sakurai, K.; Raghavan, R.; Kahne, D. J. Am. Chem. Soc. 1999, 121, 6176.

(23) Higher yields for the glycosylation reaction were obtained when the 4-OH group of the sulfoxide donor was protected with a chloroacetyl group, which was subsequently exchanged for the isovaleroyl group. Nevertheless, the route presented here is shorter with similar overall yields.

(24) (a) Although we have developed efficient syntheses for protected derivatives of $\mathrm{L}$ - and D- $\beta$-hydroxyenduracidine with fully elaborated five-membered cyclic guanidine, ${ }^{24 \mathrm{~b}}$ the incorporation of such amino acids into oligopeptides proved to be challenging because of low coupling yields under a variety of activation conditions. These problems were traced back to the presence of the cyclic guanidine and the specific protecting group pattern employed. Therefore, we opted to use the shown L- and D- $\beta$ hEnd-precursor amino acids. The details of these studies as well as the late-stage conversion of the $\mathrm{N}, \mathrm{O}$-acetals to the cyclic guanidines found in the mannopeptimycins will be described in a separate account. (b) Schwörer, C. J.; Oberthür, M. Eur. J. Org. Chem. 2009, 6129.

(25) Weck, S.; Opatz, T. Synthesis 2010, 2393; and references cited therein.

(26) Crich, D.; Cai, W. J. Org. Chem. 1999, 64, 4926.

(27) CCDC-881286 contains the supplementary crystallographic data for carbamate 19. This data can be obtained free of charge from The Cambridge Crystallographic Data Centre via www.ccdc.cam.ac.uk/data_request/cif.

(28) For a compilation of ${ }^{1} J_{\mathrm{C}, \mathrm{H}}$ coupling constants of various hexopyranosides, see: Bock, C.; Pedersen, J. J. Chem. Soc., Perkin Trans. 2 1974, 293.

(29) In this case, an inverse addition protocol (addition of $\mathrm{Tf}_{2} \mathrm{O}$ to Boc-L-Pro-OMe at $-70^{\circ} \mathrm{C}$, then addition of sulfoxide 1) and raising the reaction temperature to r.t. over $5 \mathrm{~h}$ proved to be superior to standard activation conditions (preactivation of donor 1 with $\mathrm{Tf}_{2} \mathrm{O}$ at $-70^{\circ} \mathrm{C}$, then addition of Boc-L-Pro$\mathrm{OMe}$ and conducting the reaction at $-25^{\circ} \mathrm{C}$ ), which afforded glycosyl carbamate 22 in only $50 \%$ yield.

(30) The substantially lower yields are a result of an incomplete conversion. Because of the instability of the dipeptide acceptor under the glycosylation conditions at temperatures $>-25^{\circ} \mathrm{C}$, the reaction temperature could not be raised any further.

(31) (a) Kunz, H.; Zimmer, J. Tetrahedron Lett. 1993, 34, 2907. (b) Leenders, R. G. G.; Ruytenbeek, R.; Damen, E. W. P.; Scheeren, H. W. Synthesis 1996, 1309. (c) Gum, A. G.; Kappes-Roth, T.; Waldmann, H. Chem.-Eur. J. 2000, 6, 3714. (d) Knoben, H.-P.; Schlüter, U.; Redlich, H. Carbohydr. Res. 2004, 339, 2821. (e) Bunnelle, W. H. J. Org. Chem. 2011, 76, 5429.

(32) Leenders, R. G. G.; Scheeren, H. W. Tetrahedron Lett. 2000, 41,9173 
(33) André, S.; Specker, D.; Bovin, N. V.; Lensch, M.; Kaltner, H.; Gabius, H.-J.; Wittmann, V. Bioconjugate Chem. 2009, 20, 1716.

(34) Henry, K. J. Jr.; Lineswala, J. P. Tetrahedron Lett. 2007, 48, 1791.

(35) Shaikh, A. Y.; Sureshkumar, G.; Pati, D.; Gupta, S. S.; Hotha, S. Org. Biomol. Chem. 2011, 9, 5951.

(36) Sakaitani, M.; Ohfune, Y. J. Org. Chem. 1990, 55, 870.

(37) Interestingly, the glycosylation of different carbamateprotected vancomycin aglycons was more efficient using trichloroacetimidate donors with $\mathrm{BF}_{3}$ activation compared to sulfoxides with $\mathrm{Tf}_{2} \mathrm{O}$ activation. ${ }^{16 a, b}$ Because of the different protecting groups used in these independent studies, a direct comparison of these results is possible only to a certain extent. In addition, a direct comparison between $\mathrm{BF}_{3}$ and TMSOTf activation of the same trichloroacetimidate donor is lacking. The same is true for the studies of the Romersberg group, ${ }^{13 \mathrm{~g}}$ where donor/activator systems that presumably led to glycosyl triflates also performed worse than trichloroacetimidates activated with $\mathrm{BF}_{3}$. Nevertheless, it is tempting to speculate that carbamate glycosylation could account for the poor yields obtained for the glycosyl triflates in these cases.

(38) $\mathrm{BF}_{3}$ and TMSOTf show similar reactivities in Lewis acid catalyzed Diels-Alder reactions, whereas no such data is available for the complexation of imines or imidates:

(a) Hilt, G.; Pünner, F.; Möbius, J.; Naseri, V.; Bohn, M. Eur. J. Org. Chem. 2011, 5962. (b) Hilt, G.; Nödling, A. Eur. J. Org. Chem. 2011, 7071.

(39) Kast, J.; Hoch, M.; Schmidt, R. R. Liebigs Ann. Chem. 1991, 481.

(40) Charbonnier, F.; Penadés, S. Eur. J. Org. Chem. 2004, 3650. 